\title{
COORDINATED VENDOR-BUYER SUPPLY CHAIN MODEL WITH TRANSPORTATION COST UNDER DIESEL PRICE UNCERTAINTY
}

\author{
by \\ Amanpreet Singh Pabla \\ B. Eng, 2014, Ryerson University

\begin{abstract}
A MRP
presented to Ryerson University

in partial fulfillment of the

requirements for the degree of

Master of Engineering in the Program of

Mechanical and Industrial Engineering
\end{abstract}

Toronto, Ontario, Canada, 2016

CAmanpreet Singh Pabla 2016 


\section{AUTHOR'S DECLARATION}

I hereby declare that I am the sole author of this MRP. This is a true copy of the MRP, including any required final revisions.

I authorize Ryerson University to lend this MRP to other institutions or individuals for the purpose of scholarly research.

I further authorize Ryerson University to reproduce this MRP by photocopying or by other means, in total or in part, at the request of other institutions or individuals for the purpose of scholarly research.

I understand that my MRP may be made electronically available to the public. 


\title{
ABSTRACT
}

\author{
Amanpreet Singh Pabla \\ Master of Engineering \\ Mechanical Engineering \\ Ryerson University \\ 2016
}

This project focuses on supply chain coordination model between vendor and buyer with emphasis on transportation cost. The objective is to minimize the supply chain cost which comprises of order cost, setup cost, vendor holding, buyer holding, shortage cost and finally transportation cost. The model developed in this project determines the optimal order size, number of shipments, and reorder point while simultaneously accounting for the uncertainties in diesel price. Uncertainty in price of diesel is also developed using mean reverting process. To date, the impacts diesel price uncertainty and transportation cost in the supply chain policy is not very well known. This report provides an analysis by altering the multiple variables impacting transportation costs such as the truck type, feature, environmental condition, route, weight and driving style. This analysis demonstrates how changes in truck variables impact the expected total cost thereby making it extremely critical for corporations to mitigate costs strategically. 


\section{ACKNOWLEDGEMENTS}

Dr. Mohamed Wahab Mohamed Ismail, PhD, P.Eng., Ryerson University

I am grateful to my supervisor for the opportunity to pursue this Master's project in a specialized area of interest. I wish to express my sincere appreciation and gratitude to him for his guidance throughout the course of this project. His timely feedback and support kept me motivated and gave me confidence to complete this project. Despite his busy schedule, his time management and attention to detail are qualities I will carry forward with me even after this project.

Anup Suresh, M.Eng., Ryerson University

Sincere thanks to Mr. Suresh for his valuable inputs on research techniques and technical writing which helped me gather and present my work in a clear and concise manner. 


\section{DEDICATION}

This project work is dedicated to my parents Balvir Singh Pabla, Parminder Kaur Pabla, grandfather Harjit Singh Pabla and my brother Sunpreet Singh Pabla who have been my pillars of strength throughout my life. Without their love, support and encouragement, I would not have made it this far. 


\section{TABLE OF CONTENTS}

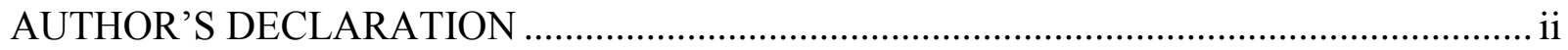

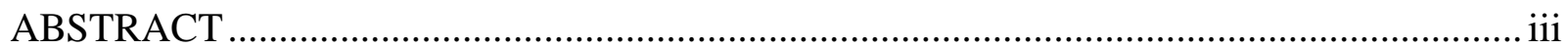

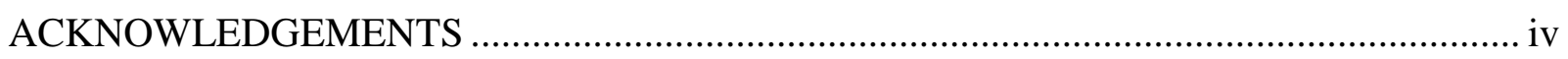

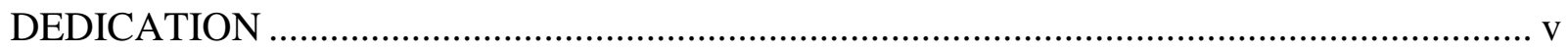

TABLE OF CONTENTS ……………………………............................................... vi

LIST OF FIGURES \& TABLES …………………........................................................ vi

NOMENCLATURE ................................................................................................. vii

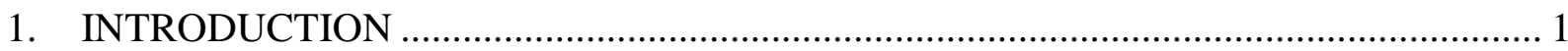

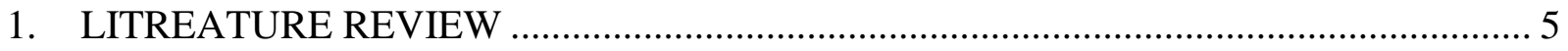

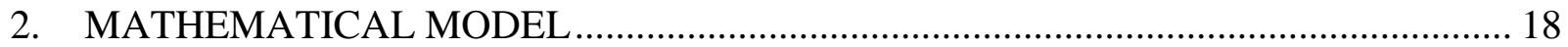

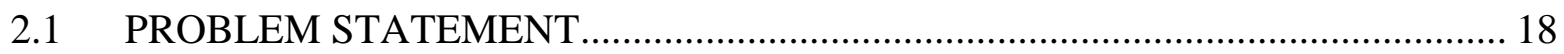

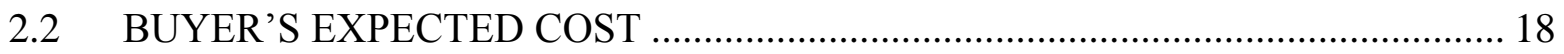

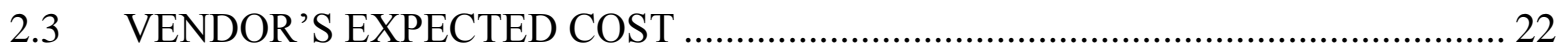

2.4 EXPECTED TOTAL COST PER UNIT TIME ................................................... 22

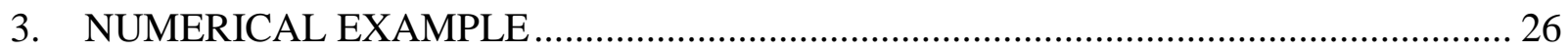

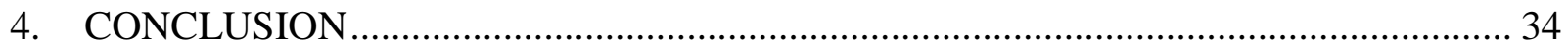

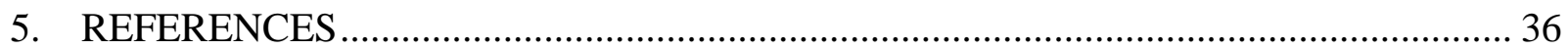

\section{LIST OF FIGURES \& TABLES}

Figure 1: Global $\mathrm{CO}_{2}$ emissions and transportation industry $\mathrm{CO}_{2}$ emissions (Jofred and Oster, 2011)

Figure 2: 2010 Distribution of world carbon dioxide emissions from fuel combustion (Environment Canada, 2013) ............................................................................................... 5

Figure 3: Tractor trailer energy losses (USDOE) ………...................................................... 7

Figure 4: Diesel Engines market share in 2013 (Oak Ridge National Laboratory, 2014) .............. 7 


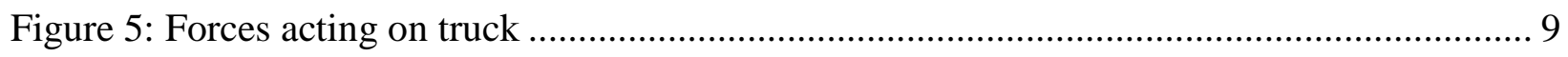

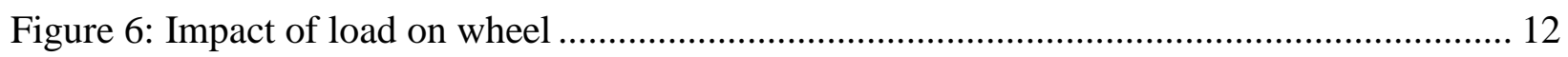

Figure 7: Tire inflation impact on fuel economy (Goodyear)........................................... 12

Figure 8: Aerodynamic drag around tractor trailer (Curry et al., 2012) ................................... 15

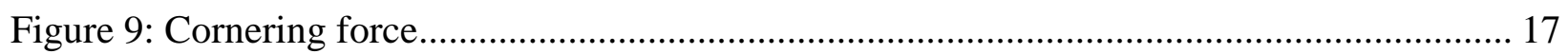

Figure 10: Diesel price historically from Jan. 3, 2012 to May 7, 2016 .................................. 20

Table 1: Canada's emission trends report published GHG emissions by economic sector

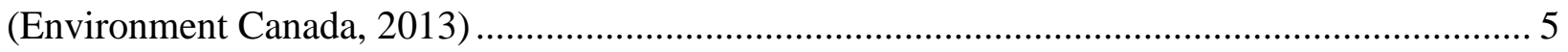

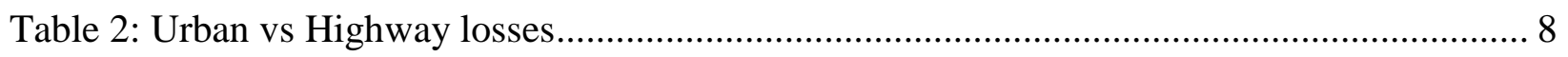

Table 3: Energy consumed by various factors can be further investigated (Ehsani and Fadai,

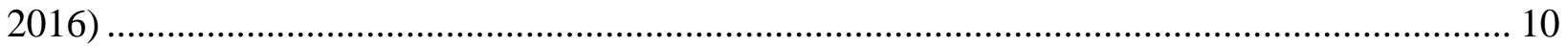

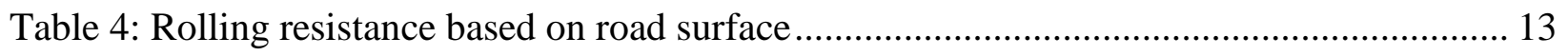

Table 5: Impact of speed on aerodynamics and rolling resistance losses.............................. 14

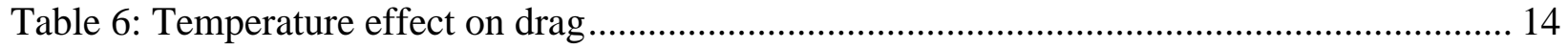

Table 7: Coefficient of drag of various parts on truck ....................................................... 16

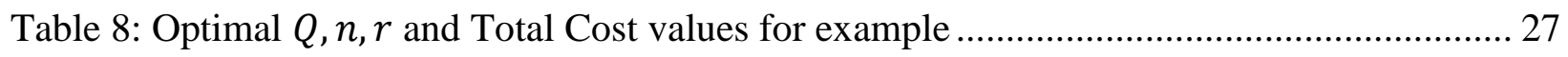

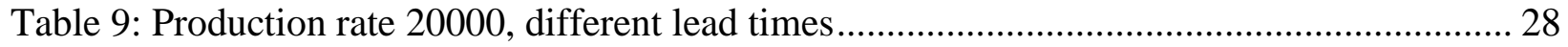

Table 10: Varying production rate and lead time vs total cost ............................................. 29

Table 11: Production rate 20,000 but different $n$ values .................................................. 30

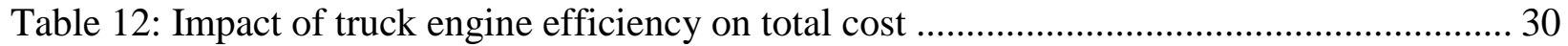

Table 13: Road gradient impact on transportation cost .................................................. 31

Table 14: Aerodynamic resistance impact on transportation cost ........................................ 31

Table 15: Truck frontal area impact on transportation cost ................................................ 31

Table 16: Temperature $\left({ }^{\circ} \mathrm{C}\right)$ impact on transportation cost................................................... 32

Table 17: Product weight impact on transportation cost ................................................... 32

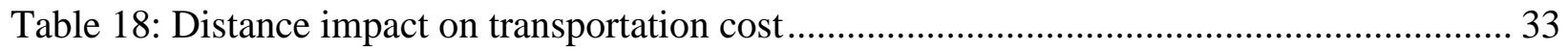

Table 19: Driving style impact on transportation cost................................................... 33 


\section{NOMENCLATURE}

\begin{tabular}{|c|c|}
\hline$m_{\text {empty }}$ & Truck only weight \\
\hline$m_{\text {trailer }}$ & Empty trailer weight \\
\hline$m_{P}$ & Product weight \\
\hline$g$ & Acceleration of gravity \\
\hline$\theta$ & Road gradient \\
\hline$d_{g}$ & Distance traveled with gravity force \\
\hline$C_{i}$ & Mass correction factor for rotational inertia acceleration \\
\hline$M_{f r}$ & Rotational mass of vehicle \\
\hline$S$ & Driving style factor \\
\hline$a$ & Acceleration rate \\
\hline$d_{i}$ & Distance traveled with acceleration \\
\hline$C_{r}$ & Rolling resistance \\
\hline$\Phi_{t}$ & Temperature factor effects of rolling and tires resistance \\
\hline$d_{r}$ & Distance travelled with rolling resistance \\
\hline$\lambda_{s}$ & Pavement effects on rolling and tires resistance \\
\hline$\rho_{\text {air }}$ & Density of air \\
\hline$A_{f}$ & Frontal area of vehicle \\
\hline$C_{d}$ & Aerodynamic resistance coefficient \\
\hline$v_{r}^{2}$ & Relative vehicle speed with wind effect \\
\hline$d_{a}$ & Distance traveled with aerodynamic resistance \\
\hline$v$ & Speed \\
\hline$R$ & Path radius from center of gravity \\
\hline
\end{tabular}




\begin{tabular}{|c|c|}
\hline$C_{a v}$ & Cornering stiffness \\
\hline$d_{c}$ & Distance traveled when turning or on ramp \\
\hline$\eta_{\text {motor }}$ & Engine efficiency \\
\hline$e_{v}$ & Wind exposure \\
\hline$P$ & Production Rate \\
\hline$D$ & Demand rate \\
\hline$h_{v}$ & Holding cost for vendor \\
\hline$\vartheta_{v}$ & Setup cost for vendor \\
\hline$\vartheta_{b}$ & Order cost for buyer \\
\hline$h_{b}$ & Holding cost for buyer \\
\hline$\rho_{\text {short }}$ & Shortage cost \\
\hline $1 / \tau$ & Lead time in days over 1 year (365 days) \\
\hline$\beta$ & Mean reversion speed \\
\hline$\mu$ & Long term mean \\
\hline$\sigma$ & Volatility of the process \\
\hline$\alpha$ & Energy per litre of diesel \\
\hline$\zeta_{t}$ & Diesel price at time $t$ \\
\hline$n$ & \# of shipments within 1 setup of vendor \\
\hline$Q$ & Lot size \\
\hline$r$ & Reorder point \\
\hline
\end{tabular}




\section{INTRODUCTION}

In today's consumer market, dynamics are ever so changing and competition is fierce. Companies are thereby compelled to find and adopt effective methodologies to streamline their operations. Corporations with a global supply chain are constantly under pressure to mitigate internal (organizational) and external risks. Internal risks include long lead times, production bottlenecks, material shortages and quality/performance risks. External risks, although make up a small portion of the possible risks, are highly unpredictable and random such as customs, foreign policies and unforeseen instability in different parts of the world. A poor supply chain can incapacitate a company resulting in decreased sales, increased share price volatility, and operating income (Dittmann, 2014). Thus, businesses try to adopt the best practices to manage inventory and purchase orders to decrease the overall cost of the supply chain.

Supply chain costs are typically impacted by changing production, inventory, warehousing, logistics and transportation operations. When enhancing supply chain, thorough consideration is given to transportation costs due to its extremely high volatility. The increased fluctuation in diesel prices in the past decade has resulted in transportation costs constantly oscillating between high and low (Russell et al., 2014). In order to mitigate these risks, IKEA, the renowned furniture manufacturing company, opened their first factory in Danville, VA in United States to maintain close proximity to the North American market. Lindquist (VP of North American market at IKEA Swedwood), stated in an interview that it makes more financial sense to reduce sourcing costs, lead times and transportation time to meets IKEA's growing demand in North America (Koenig, 2008). Similarly, Tesla Motors, a growing electric car manufacturer, decided

to move $1000 \mathrm{lbs}$ of battery packs from Thailand to California. The logistics and risks (transportation costs, fluctuating diesel prices) associated with shipping battery packs from offshore facilities to North America were so immense that the company did not see this as a robust strategy. When diesel prices increase, it is more often than not, a better strategy for companies to decrease the distance between their distribution center and the retailer (and eventually consumers). Companies can thereby also make a larger lot sizes with less frequent shipments. Therefore, companies should develop a strategy in their supply chain model to adapt to diesel price uncertainties. 
One strategy that various firms exercise is collaboration of supply chain coordination. Coordination between vendor and the buyer can reduce overall cost and inventory level. Originally, the single buyer inventory model was introduced by Goyal (1976). This was followed by Hill (1997) who illustrated how consideration to general equal shipment policy can reduce the total cost for a particular problem. However, this illustration was ambiguous and did not guarantee to provide a globally optimal solution. Later, a model was presented by Goyal (2003) introduced imperfect products into the inventory model. Banerjee (2007) explored a model which included a single manufacturer and 3 different customers/retailers. The study illustrated a numerical example using heuristic two-phase solution algorithm (Banerjee at al., 2007).

Another aspect that was explored was the option for backorder price discount and effect of reduced ordering cost. The buyer proposes backorder price discount to their customers in order to encourage them to backorder (Lin, 2009). After much iteration of various studies throughout many years, a model was assimilated in 2009 wherein the coordination between vendor and buyer was analyzed. The objective of this study was to minimize the total expected cost (Sajadieh et al, 2009). A study later introduced the transportation congestion being impactful to supply chain costs. It introduced how distribution decision and market supply quantity is affected of traffic congestion (Konur and Geunes, 2011). Furthermore, models were developed which did not allow for any shortage called Overlapping production cycles with immediate delivery (OPCI) and Overlapping production cycles with delayed delivery (Glock, 2012). A literature review conducted by Glock (2012) discussed coordinated inventory replenishment, keeping in mind total cost of the supply chain. Various models were discussed, for example basic integrated inventory models and extended integrated inventory models (Glock, 2012). Another aspect was introduced to supply chain by Wee and Widyadana (2013). They introduced a stochastic machine unavailability time to inventory model which provides an insight into how the implementation of JIT systems can impact a company. Recently, a publication took into consideration the quality of a product, deterioration (Lee and Kim, 2014) and imperfect production process incorporation screening (Dey and Giri, 2014). 
Transportation has impact on sustainability and environmental performance. Hence, decisions need to be made by companies keeping in mind their stakeholders, modes of transportation and just-in-time (JIT) policies (Jofred and Oster, 2011). Diesel usage has impact on carbon emission because combustion of diesel generates carbon dioxide, the predominant greenhouse gas linked to global warming. Furthermore, the local air is polluted with nitrogen oxides and volatile organic compounds that are extremely toxic to human health (Li et al., 2008). Globally, the transportation industry contributes nearly $24 \%$ of $\mathrm{CO}_{2}$ emissions and $15 \%$ overall Greenhouse gas (GHG) emissions as illustrated in Figure 1.
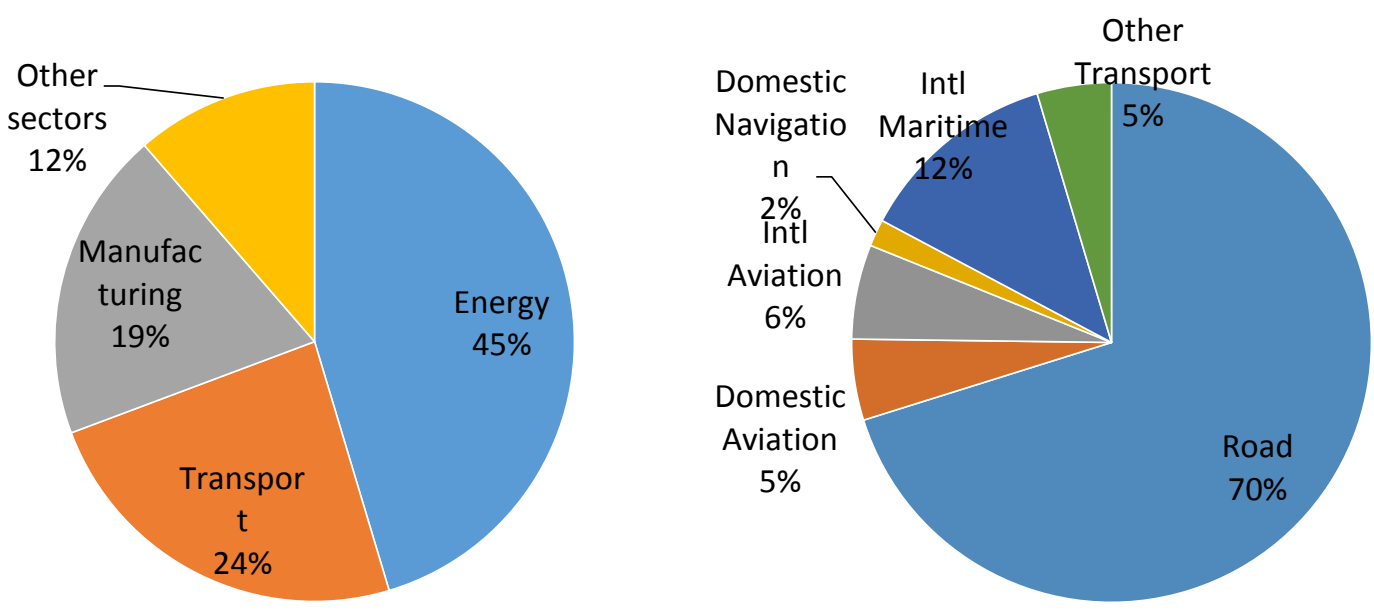

Figure 1: Global $\mathrm{CO}_{2}$ emissions and transportation industry $\mathrm{CO}_{2}$ emissions (Jofred and Oster, 2011)

Many companies today are leading the efforts to reduce GHG emissions. Companies are even asking their suppliers to submit emissions report data directly to them. Growing number of establishments are making public commitments to reduce their supply chain GHG emissions. For example, Wal-Mart announced in 2010 to reduce their GHG by 20 million metric tons (Environment Protection Agency, 2010). Similarly, Procter \& Gamble announced that it will develop its own questionnaire for collecting emissions data from their suppliers. Many companies are trying to manage their GHG like Acatel-Lucent, American Electric Power, Applied Materials, Dell, IBM, Intel, Johnson \& Johnson, Kimberly Clark Corporation, PepsiCo, and Steelcase (Environment Protection Agency, 2010). The Canadian government is also supporting the global emissions reductions under the Copenhagen Accord (Environment Canada, 
2013). Canada's emissions trends report demonstrated that Canada is regulating GHG emissions using a sector by sector method.

To date, there has been no research that introduces energy (diesel) price uncertainty into supply chain policy. For the first time, diesel price uncertainty, stochastic lead-time, and type of truck is introduced into coordinated vendor-buyer inventory model. The studies currently available do not consider transportation costs when modelling the total expected cost of supply chain.

This report discusses a mechanical model and explains the main reasons for high diesel consumption by truck. It is critical to understand how various factors influence consumption of diesel by a truck transporting goods for a company. Energy used to overcome gravity, acceleration, rolling resistance, drag resistance, and cornering losses are discussed in depth. There is heavy focus on truck diesel consumption and presents various suggestions to reduce this consumption. Results show, that as the diesel price increases, the optimal order quantity increases while the optimal reorder level decreases. Also, the impacts of temperature, product weight, truck features, driving style, road gradient, aerodynamics, engine efficiency and distance travelled vs cost of transportation has also been discussed. The report will also show the carbon emission generated by burning diesel.

This report is organized as follows: Section 2 presents a literature review primarily focused on truck diesel consumption. Section 3 explains the mathematical model for coordinated vendorbuyer inventory policy. Section 4 demonstrates a numerical example and Section 5 presents the conclusions. 


\section{LITREATURE REVIEW}

In order to reduce supply chain cost, transportation must be looked at in detail. It is in the interest of companies to understand the importance of various factors that influence diesel consumption in trucks. Not only is it important for cost of transportation but also from $\mathrm{CO}_{2}$ footprint of the organization. As discussed earlier, there has been a lot of emphasis on greenhouse gasses emission from many customers and government entities. Governments in many parts of the world have started implementing carbon emission regulations like carbon cap, cap-and-trade, and tax policies (Toptal et al., 2014).

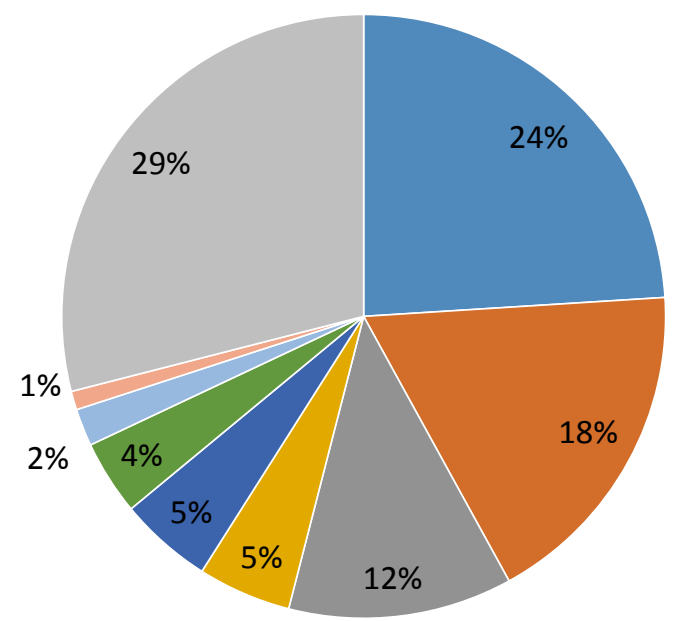

$$
\begin{aligned}
& \text { China } \\
& \text { United States } \\
& \text { European Union } \\
& \text { India } \\
& \square \text { Russia } \\
& \square \text { Japan } \\
& \text { Canada } \\
& \square \text { Brazil } \\
& \square \text { Rest of World }
\end{aligned}
$$

Figure 2: 2010 Distribution of world carbon dioxide emissions from fuel combustion (Environment Canada, 2013)

Table 1: Canada's emission trends report published GHG emissions by economic sector (Environment Canada, 2013)

\begin{tabular}{|c|c|c|c|c|}
\hline $\mathrm{Mt} \mathrm{CO}_{2}$ equivalent & 1990 & 2000 & 2005 & 2011 \\
\hline Transportation & 128 & 155 & 168 & 170 \\
\hline Oil and Gas & 101 & 150 & 162 & 163 \\
\hline Electricity & 94 & 129 & 121 & 90 \\
\hline Buildings & 70 & 82 & 84 & 84 \\
\hline Emissions Intensive \& Trade Exposed Industries & 93 & 85 & 87 & 78 \\
\hline Agriculture & 54 & 66 & 68 & 68 \\
\hline Waste and Others & 50 & 51 & 49 & 49 \\
\hline NATIONAL GHG TOTAL & 591 & 718 & 737 & 702 \\
\hline
\end{tabular}


Truck transportation is most commonly used method to deliver goods and contribute the most towards $\mathrm{CO}_{2}$ emissions. This report will discuss the various factors which impact diesel consumption of a truck and eventually result in high or low supply chain cost.

As seen in the Table 1, transportation has a lot to do with GHG emissions. In order to address this sector, companies must have a closer look at their supply chains. They have to be careful as to who they are partnering with to deliver their products. Businesses must understand how they can help reduce the supply chain cost by incorporating transportation cost into the total cost of supply chain. Calculation of diesel consumption is most widely done using energy based approach and activity based approach (Jofred and Oster, 2011). Diesel cost is the second largest expense in transportation just after labour costs.

There are various classes of trucks which are categorized by gross weight rating. (Oak Ridge National Laboratory, 2014)

- Class 1-6,000 kg or less, example: minivan, cargo van, SUV, pickup truck

- Class 2-6,001 to $10,000 \mathrm{~kg}$, example: minivan, cargo van, full size pickup, step van

- Class $3-10,001$ to $14,000 \mathrm{~kg}$, example: walk in, box truck, city delivery, heavy duty pickup

- Class 4-14,001 to 16,000 kg, example: large walk in, box truck, city delivery

- Class 5-16,001 to 19,500 kg, example: bucket truck, large walk in, city delivery

- Class 6 - 19,5001 to 26,000 kg, example: beverage truck, single axle, school bus, rack truck

- Class $7-26,001$ to $33,000 \mathrm{~kg}$, example: refuse, furniture, city transit bus, truck tractor

- Class 8-33,001 or over, example: cement truck, truck tractor, dump truck, sleeper

Diesel consumption is dependent on various factors of the specific transport truck. United States Department of Energy (USDOE) produced a report which gives a breakdown of various losses experienced by a tractor trailer: 


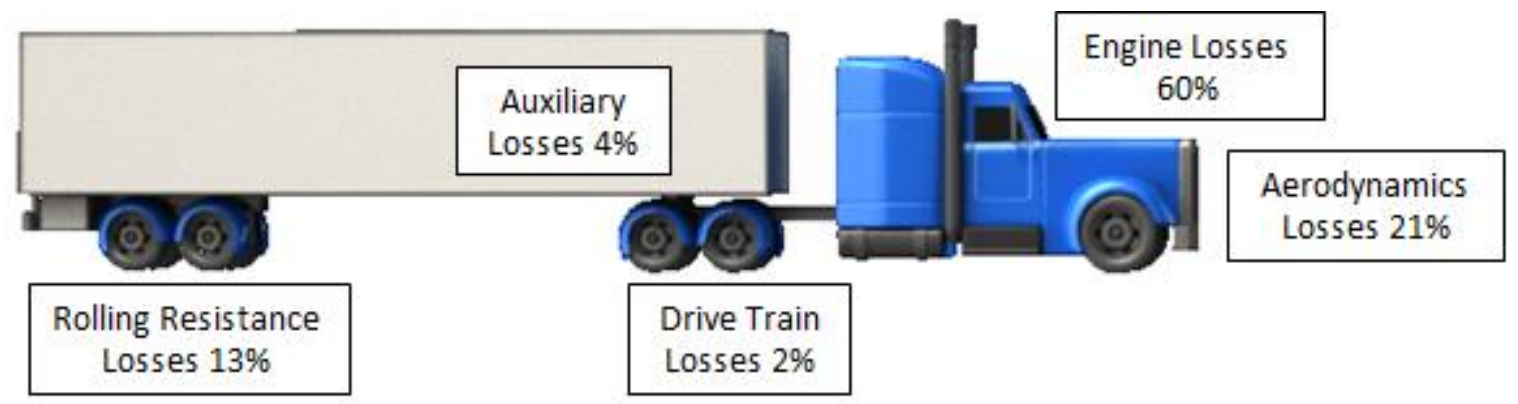

Figure 3: Tractor trailer energy losses (USDOE)

The diesel consumption is heavily influenced by engine losses. As seen in Figure 3, 60\% of the energy loss is due to inefficiency in the truck engine. A market report on vehicle technologies reveals that Navistar in 2009 held $77 \%$ of heavy truck diesel engine and by $2013,47 \%$ of the engine market share was held by Cummins (see Figure 4).

A publication by Center for Alternative Fuels Engines and Emissions (CAFEE) reports that heavy duty engine generally converts $39 \%$ of the input energy into useful work and an average of $34 \%$ is rejected as exhaust gas, and rest is due to frictional, pumping, coolant losses (Thiruvengadam et al., 2014).

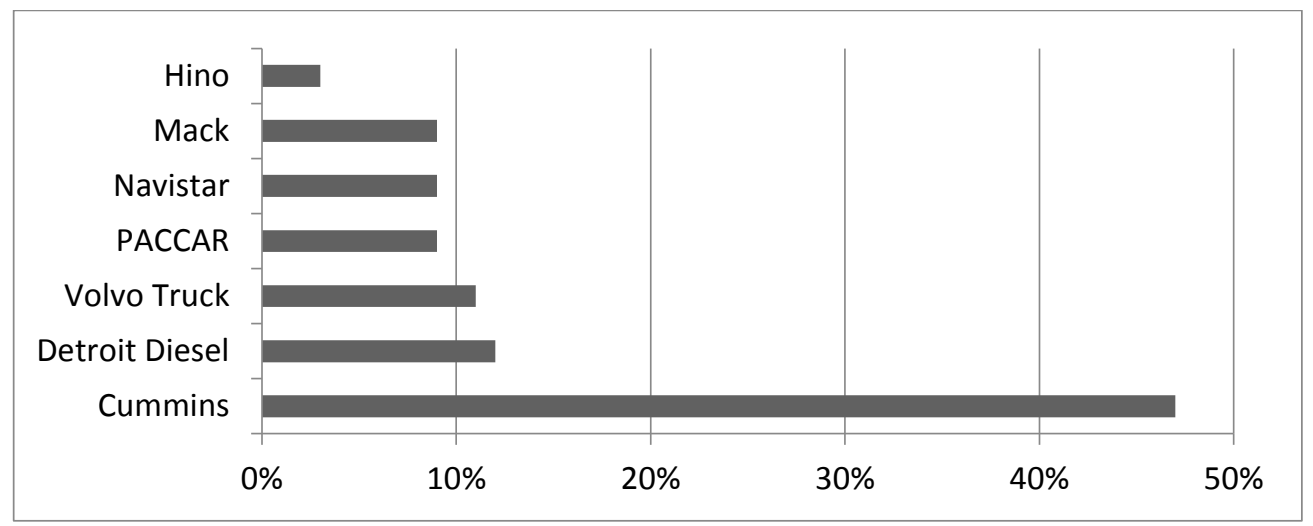

Figure 4: Diesel Engines market share in 2013 (Oak Ridge National Laboratory, 2014)

Another aspect to consider is the truck driver selection process. The reason behind this is because the cost of transportation can significantly go up based on the driving style of the driver. Welltrained drivers must be selected because they can help keep the diesel consumption cost down. According to ATA's Technology and Maintenance Council (TMC), professional and skilled drivers can produce $35 \%$ better $\mathrm{km}$ per litre than less-skilled truck operators. Many fleets can achieve a $10 \%$ diesel economy improvement through driver training. Some simple techniques 
can help reduce diesel consumption which in return reduces carbon emission and diesel cost (Whistler, 2011). An article written by fleet owner outlines some driving techniques to help reduce diesel consumption:

- Accelerating and braking smoothly and steadily

- Use cruise control where possible

- Progressive shifting techniques

- Reduce truck idling as much as possible

- Coasting when the opportunity provides itself

- Drive at lowest engine speed

- Reduce unnecessary shifting

- Limit use of cab accessories

Truck features are crucial to look at when considering to purchasing fleet for a companies' supply chain. Vehicle design has a very high impact on diesel consumption because aerodynamics losses are the greatest when driving on the highway. Consideration should be given to tractor design, trailer configuration, gap region between tractor and trailer, appendages (Patten et al., 2012).

Diesel consumption is directly related to energy used to overcome various forces by the tractor trailer. If engine losses are put aside and the focus is on other losses then below is the breakdown.

Table 2: Urban vs Highway losses

\begin{tabular}{|c|c|c|}
\hline Source & Urban & Highway \\
\hline Drivetrain & $10-15 \%$ & $5-10 \%$ \\
\hline Inertia/braking/grade & $35-50 \%$ & $0-5 \%$ \\
\hline Rolling resistance & $20-30 \%$ & $30-40 \%$ \\
\hline Auxiliary loads & $15-20 \%$ & $2-10 \%$ \\
\hline Aerodynamics losses & $10-25 \%$ & $35-55 \%$ \\
\hline
\end{tabular}

All these forces change based on various features of the vehicle. A mechanical model can be utilized to break down various forces and provide a framework explaining impact of vehicle on 
supply chain cost. The forces are first calculated separately and then combined together to get total energy loss (Ehsani and Fadai, 2016):

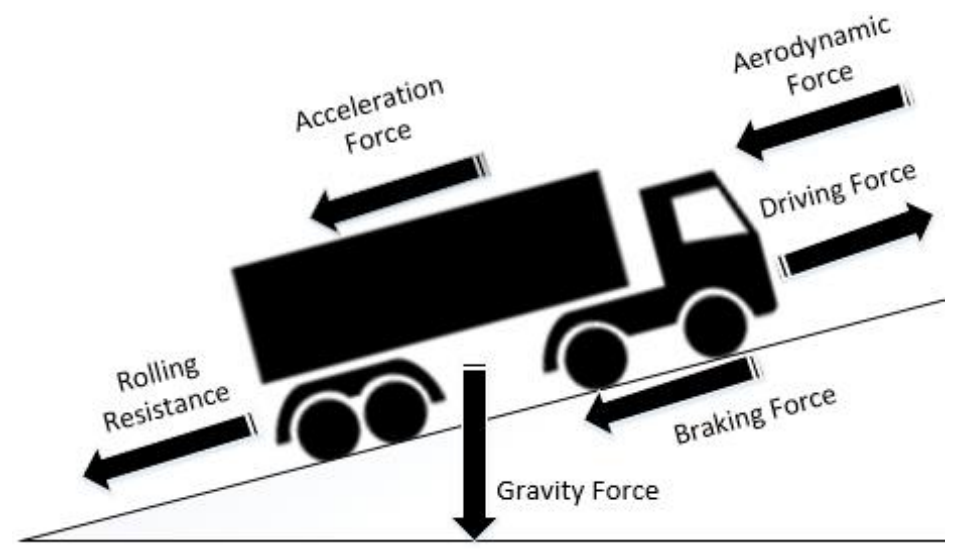

Figure 5: Forces acting on truck

$$
U=U_{g}+U_{i}+U_{r}+U_{d}+U_{c}
$$

where $U_{g}$ is the energy to overcome gravity, $U_{i}$ is the energy loss due to acceleration, $U_{r}$ is the energy to overcome rolling resistance, $U_{d}$ is loss due to drag or aerodynamic resistance, $U_{c}$ is energy consumed due to cornering losses. 
Table 3: Energy consumed by various factors can be further investigated (Ehsani and Fadai, 2016)

\begin{tabular}{|c|c|c|c|c|}
\hline $\begin{array}{c}\text { Energy } \\
\text { Loss }\end{array}$ & Expanded & Symbol & Parameter & Unit \\
\hline$U_{g}$ & $m g \sin \theta d_{g}$ & $\begin{array}{c}m \\
g \\
\theta \\
d_{g}\end{array}$ & $\begin{array}{l}\text { Vehicle weight } \\
\text { Acceleration of gravity } \\
\text { Road gradient } \\
\text { Distance traveled with gravity force }\end{array}$ & $\begin{array}{l}\mathrm{kg} \\
\mathrm{m} / \mathrm{s}^{2} \\
\mathrm{rad} \\
\mathrm{km}\end{array}$ \\
\hline $\boldsymbol{U}_{\boldsymbol{i}}$ & $C_{i} M_{f r} \operatorname{sad}_{i}$ & $\begin{array}{c}C_{i} \\
M_{f r} \\
S \\
a \\
d_{i}\end{array}$ & $\begin{array}{l}\text { Mass correction factor for rotational inertia acceleration } \\
\text { Rotational mass of vehicle } \\
\text { Driving style factor } \\
\text { Acceleration rate } \\
\text { Distance traveled with acceleration }\end{array}$ & $\begin{array}{c}- \\
\mathrm{kg} \\
- \\
\mathrm{m} / \mathrm{s}^{2} \\
\mathrm{~km}\end{array}$ \\
\hline $\boldsymbol{U}_{r}$ & $C_{r} m g \cos \theta \Phi_{t} d_{r} \lambda_{s}$ & $\begin{array}{l}C_{r} \\
m \\
g \\
\theta \\
\Phi_{t} \\
d_{r} \\
\lambda_{s}\end{array}$ & $\begin{array}{l}\text { Rolling resistance } \\
\text { Vehicle weight } \\
\text { Acceleration of gravity } \\
\text { Road gradient } \\
\text { Temperature factor effects of rolling and tires resistance } \\
\text { Distance travelled with rolling resistance } \\
\text { Pavement effects on rolling and tires resistance }\end{array}$ & $\begin{array}{l}- \\
\mathrm{kg} \\
\mathrm{m} / \mathrm{s}^{2} \\
\mathrm{rad} \\
- \\
\mathrm{kg} \\
-\end{array}$ \\
\hline$U_{d}$ & $0.5 \rho A_{f} C_{d} v_{r}^{2} s d_{a}$ & $\begin{array}{c}\rho_{a i r} \\
A_{f} \\
C_{d} \\
v_{r}^{2} \\
S \\
d_{a}\end{array}$ & $\begin{array}{l}\text { Density of air } \\
\text { Frontal area of vehicle } \\
\text { Aerodynamic resistance coefficient } \\
\text { Relative vehicle speed with wind effect } \\
\text { Driving style factor } \\
\text { Distance traveled with aerodynamic resistance }\end{array}$ & $\begin{array}{c}\mathrm{kg} / \mathrm{m}^{3} \\
\mathrm{~m}^{2} \\
- \\
\mathrm{m} / \mathrm{s} \\
- \\
\mathrm{km}\end{array}$ \\
\hline$U_{c}$ & $\left(\frac{m^{2} v^{4}}{R^{2} C_{a v}}\right) s \lambda_{s} d_{c}$ & $\begin{array}{c}m \\
v \\
R \\
C_{a v} \\
s \\
\lambda_{s} \\
d_{c}\end{array}$ & $\begin{array}{l}\text { Vehicle weight } \\
\text { Speed } \\
\text { Path radius from center of gravity } \\
\text { Cornering stiffness } \\
\text { Driving style factor } \\
\text { Type of asphalt effects of rolling and tires resistance } \\
\text { Distance traveled when turning or on ramp }\end{array}$ & $\begin{array}{l}\mathrm{kg} \\
\mathrm{m} / \mathrm{s} \\
\mathrm{m} \\
\mathrm{kN} / \mathrm{rad} \\
- \\
- \\
\mathrm{km}\end{array}$ \\
\hline
\end{tabular}




$$
\begin{gathered}
U=\left[m g \sin \theta d_{g}+C_{i} M_{f r} s a d_{i}+C_{r} m g \cos \theta \Phi_{t} d_{r} \lambda_{s}+0.5 \rho A_{f} C_{d} v_{r}^{2} s d_{a}\right. \\
\left.+\left(\frac{m^{2} v^{4}}{R^{2} C_{a v}}\right) s \lambda_{s} d_{c}\right]\left(\frac{1}{\eta_{\text {motor }}} e_{v}\right)
\end{gathered}
$$

Energy consumed due to gravity: $U_{g}=m g \sin \theta d_{g}$

The loss due to gravity is dependent on weight and gradient of the road. In order to reduce these losses in a truck, the weight has to be reduced but that means fewer products being shipped in one truck. Weight not only impacts gravitational losses but also rolling resistance, inertial acceleration and indirectly cornering losses. Choosing lighter weight trucks can significantly reduce diesel consumption. Weight saving items like cast aluminum alloy wheels can save $40 \mathrm{lbs}$ for wheel. Aluminum axle hubs, centrifuse brake drums, aluminum clutch housing, aluminum cab frame are just some suggestions that should be considered when purchasing a truck (Whistler, 2011).

Another variable that is controllable is gradient. The route picked for the truck to travel on can have a significant impact on diesel consumption. Where possible it is advised to pick route with less amount of slope. The truck has to overcome a lot more force on an inclined road. Once again there has to be due diligence behind picking the route because it is not sometimes worth the effort to take a flat route if it takes longer to deliver. Longer route incurs more cost because of diesel and operator's time. A study conducted by Oak Ridge National Laboratory validated that a severe downslope ( $<-4 \%$ grade) resulted in $10 \mathrm{~km} / 100 \mathrm{~L}$, mild downslope ( $-4 \%$ to $-1 \%$ grade) resulted in $15.6 \mathrm{~L} / 100 \mathrm{~km}$, flat terrain $(-1 \%$ to $1 \%$ grade) resulted in $32.2 \mathrm{~L} / 100 \mathrm{~km}$, mid upslope ( $1 \%$ to $4 \%$ grade) resulted in $53.4 \mathrm{~L} / 100 \mathrm{~km}$, and sever upslope (>4\%) $81.1 \mathrm{~L} / 100 \mathrm{~km}$ (Franzese, 2011). When selecting facility locations, this should be given a consideration because routes to and from facility can be big diesel saver and help reduce supply chain cost.

Energy consumed due to acceleration: $U_{i}=C_{i} M_{f r} s a d_{i}$

Acceleration losses are dependent on various vehicle parameters such as speed, weight. Generally the beginning of a vehicle movement requires a lot of energy. This contributes to 
diesel consumption. When a body that is capable of rotating, the angular momentum must be changed using torque.

Energy consumed due to rolling resistance: $U_{r}=C_{r} m g \cos \theta \Phi_{t} d_{r} \lambda_{s}$

Rolling resistance is a result of internal friction of tire as it deflects when moving. Cooler running tires are normally seen to be more fuel efficient. The resistance of tire is dependent on speed, weight, inflation pressures, tire construction, environment temperature, road surface, and tire and axle alignment (Cummins).

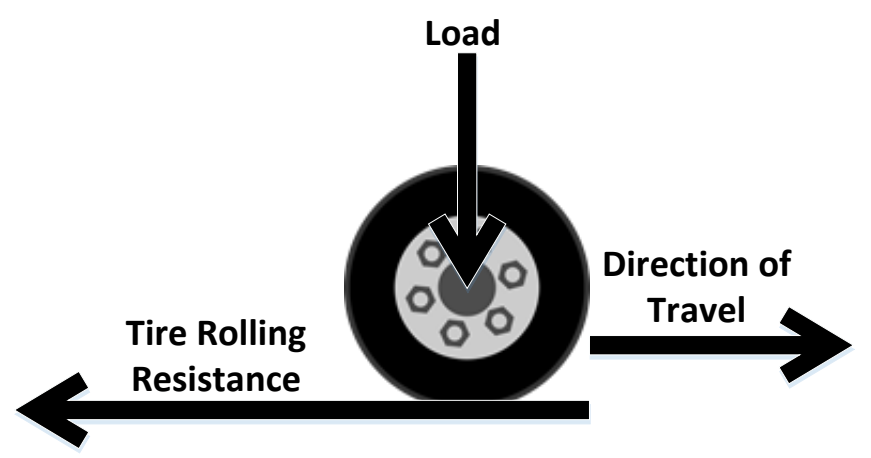

Figure 6: Impact of load on wheel

Weight and gradient discussion can be seen in energy loss due to gravity section earlier. Increased weight tends to flex the tires more. Generally speaking the loss is primarily due to resistance from tire deformation, and a little bit from tire penetration, tire slippage. Tires flex at higher speeds and in turn create more friction and higher tire temperature (Cummins). Winter diesel economy tends to be lower than that resulting from summer.

A variety of tire options can 2 improve the diesel economy of a truck. Using single wide-base tires have proven to reduce diesel consumption because they have lower rolling resistance, and aerodynamic drag.

An analysis done by Nokian Tyres show the impact of rolling resistance

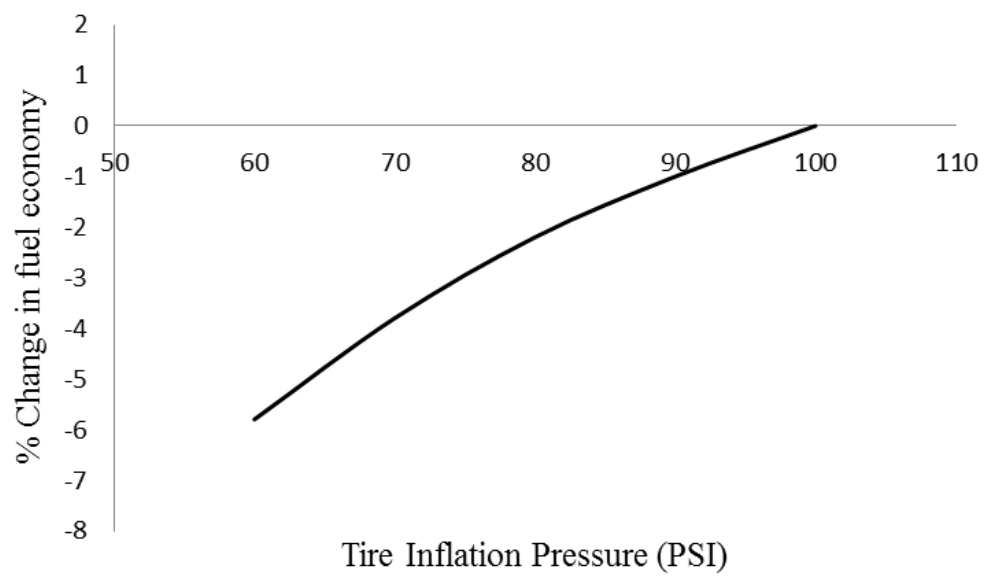

Figure 7: Tire inflation impact on fuel economy (Goodyear) 
based on different axles. Around $60 \%$ of the resistance is on trailer when fully loaded. One item noted in the analysis is that inflation pressure of the tire has a significant impact on diesel consumotion. 1\% more diesel consumption is seen with $10 \%$ under inflation (Siltanen T., 2010). When a tire is not properly inflated, they tend to flex more under load, producing heat which then uses more diesel to overcome rolling resistance. Automatic tire inflation systems can be installed to monitor and continually adjust the pressurised air in the tires.

Another impact on rolling resistance is the type of pavement the vehicle is being driver on. The diesel consumption is lower on PCC (Portland Cement Concrete) pavement by $6.21 \%$ compared to ACC (Ashphalt Concrete) pavement (Ehsani and Fadai, 2016). Typical values of coefficient of rolling resistance on various road surfaces can be seen in table below (Subbarao). Smooth textured highway surfaces yield a lower rolling resistance, whereas coarse surfaces give highest rolling resistance hence higher diesel consumption.

Table 4: Rolling resistance based on road surface

\begin{tabular}{|l|c|}
\hline \multicolumn{1}{|c|}{ Road Surface } & Rolling Resistance Coefficient \\
\hline Pneumatic tire of a car rolls & 0.015 \\
On a coarse stone road surface & 0.015 \\
On a fine stone road surface & 0.015 \\
On a rolled asphalt mixed aggregate road surface & 0.012 \\
On a impacted coarse gravel road surface & 0.025 \\
On a mixed bituminous macadam road surface & 0.05 \\
On a soil road surface & $0.1-0.35$ \\
On a field road surface & $0.006-0.01$ \\
\hline Pneumatic truck tire rolls on an asphalt mixed aggregate road & \\
surface & $0.14-0.24$ \\
\hline Steel wheel rolls on a field road surface & $0.001-0.002$ \\
\hline Steel wheel on a railroad surface & \\
\hline
\end{tabular}

Analysis by Nokian Tyres also shows the impact of all season tires vs winter tires. It is essential that in winter time tires have tread pattern which are deep enough and open with siping (Siltanen T. , 2010). 
Energy consumed due to aerodynamics resistance: $U_{d}=0.5 \rho A_{f} C_{d} v_{r}^{2} s d_{a}$

One of the biggest forces that consume a lot of energy is aerodynamics resistance (Cummins). This force is the result of pressure imbalance acting on the vehicle as the air passes by it. Pressure drag is dominant due to larger surface which is perpendicular to main flow direction of air. This is highly dependent on density, frontal area, speed, and driving style. Aerodynamics is the biggest factor over $80 \mathrm{~km} / \mathrm{hr}$ (Patten et al., 2012).

Not every truck comes equipped with aerodynamics features. A vehicle must consider frontal area, outline of tractor cab, gap between tractor and trailer, and the underbody of truck to best reduce the aerodynamic drag. At $80 \mathrm{~km} / \mathrm{hr}, 10 \%$ diesel reduction can be accomplished by simply reducing $20 \%$ drag.

Table 5: Impact of speed on aerodynamics and rolling resistance losses

\begin{tabular}{|c|c|c|}
\hline Vehicle Speed & Aerodynamic & Rolling \& Accessories \\
\hline $32 \mathrm{~km} / \mathrm{hr}$ & $28 \%$ & $72 \%$ \\
\hline $53 \mathrm{~km} / \mathrm{hr}$ & $33 \%$ & $66 \%$ \\
\hline $64 \mathrm{~km} / \mathrm{hr}$ & $36 \%$ & $64 \%$ \\
\hline $80 \mathrm{~km} / \mathrm{hr}$ & $50 \%$ & $50 \%$ \\
\hline $96 \mathrm{~km} / \mathrm{hr}$ & $62 \%$ & $38 \%$ \\
\hline $105 \mathrm{~km} / \mathrm{hr}$ & $67 \%$ & $33 \%$ \\
\hline $113 \mathrm{~km} / \mathrm{hr}$ & $70 \%$ & $30 \%$ \\
\hline
\end{tabular}

The Canadian climate not only has impact on rolling resistance but also on drag because it changes the density of air. Usually the air density is $1.225 \mathrm{~kg} / \mathrm{m}^{3}$. In winter temperatures, aerodynamic drag is can impact can be greater than $20 \%$ greater than standard temperatures (Patten et al., 2012).

Table 6: Temperature effect on drag

\begin{tabular}{|c|c|}
\hline Temperature $\left({ }^{\circ} \mathrm{C}\right)$ & $\%$ increase in drag \\
\hline+15 & 0 \\
\hline 0 & 5.5 \\
\hline-15 & 11.6 \\
\hline-30 & 18.5 \\
\hline
\end{tabular}

In efforts to reduce aerodynamics drag, it is important to design 4 point on tractor trailer (Curry et al., 2012): 
1. The tractor must smooth and allow the air to transition from top of the tractor to top of the trailer

2. The gap between the cab and trailer must be minimized and aero skirts must be utilized.

3. The air should not be able to get under the trailer

4. The rear of trailer should be rounded and be extended to create more aerodynamic shape

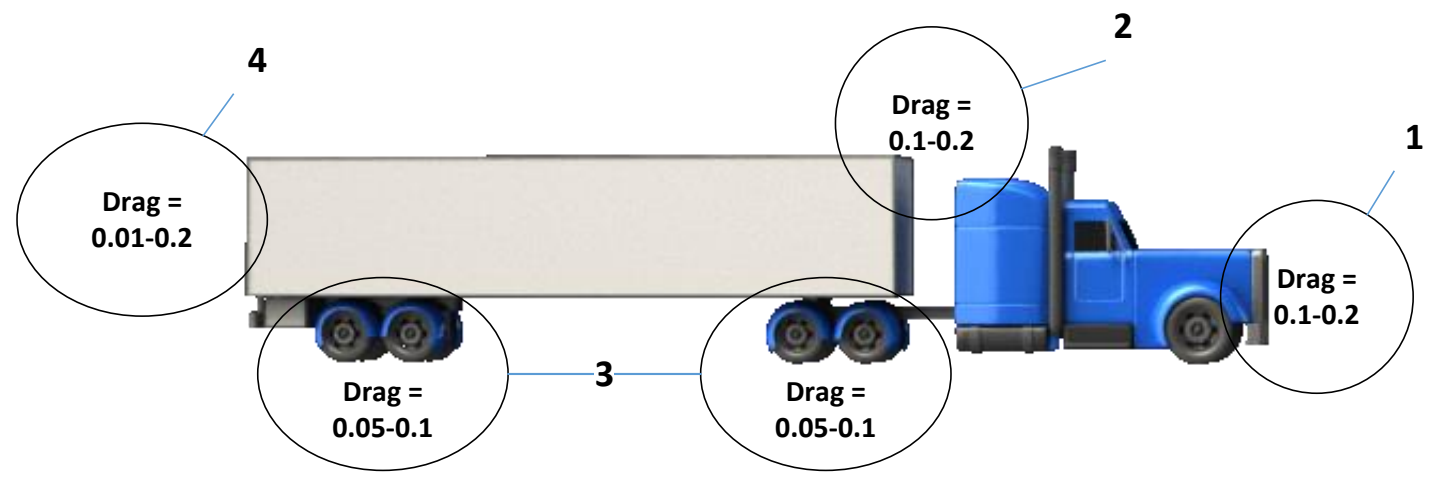

Figure 8: Aerodynamic drag around tractor trailer (Curry et al., 2012)

In order to improve the aerodynamics of the cab, few suggestions are (Cummins):

- Full Roof Deflector

- Fairings

- Sloped Hood

- $\quad$ Round Corners

- Aero Bumper

- Air Dam

- Aero Headlights

- Slanted Windshield

- Curved Windshield

- Aero Mirrors

- Side Extenders

- $\quad$ Side Skirts

- Under Hood Air Cleaner(s)

- Concealed Exhaust System

- Recessed Door Hinges

- Grab Handles 
Aerodynamic drag-reducing devices were tested using wind tunnel on tractor-trailers by NRC (Patten et al., 2012) which shows the aerodynamics coefficient of various components on tractor trailer:

Table 7: Coefficient of drag of various parts on truck

\begin{tabular}{|c|c|c|}
\hline Truck parts & $\left.\Delta \mathbf{C}_{\mathbf{D}} \mathbf{( 1 0 0} \mathbf{~ k p h}\right)$ & Annual diesel savings (L) \\
\hline OEM side mirrors & -0.016 & -938 \\
\hline OEM bug deflector & -0.015 & -903 \\
\hline OEM fender mirrors & -0.010 & -588 \\
\hline Engine cooling inlet blocked & 0.000 & 0 \\
\hline Sun visor with roof deflector & 0.001 & 54 \\
\hline Hub caps (truck and trailer) & 0.002 & 120 \\
\hline Deer bumper & 0.002 & 120 \\
\hline Wrap-around splash guards & 0.005 & 292 \\
\hline Prototype roof deflector filler & 0.014 & 825 \\
\hline Fifth wheel forward 254mm & 0.016 & 982 \\
\hline OEM tank and cab skirts & 0.027 & 1596 \\
\hline OEM side extenders & 0.042 & 2499 \\
\hline OEM roof deflector & 0.072 & 4318 \\
\hline
\end{tabular}

Energy consumed due to cornering losses: $U_{c}=\left(\frac{m^{2} v^{4}}{R^{2} C_{a v}}\right) s \lambda_{s} d_{c}$

Cornering losses come into effect when truck is turning or going onto a ramp either on or off the highway. Centrifugal force acting on the vehicle produces a side thrust when taking a turn. Cornering loss is produced by vehicle tire when cornering. The forces is dependent on vehicle weight, speed, radius of the path from the vehicle center of gravity, cornering stiffness, driving behavior, type of asphalt. Cornering stiffness is when a tire is at an angle and a side force acts perpendicular to the plane of the wheel. Slip angle is dependent on tire flexibility, load, and several other factors like camber angle. Cornering angle is at its highest, half way through the turn. Typically with 6 degree angle, the cornering forces is the greatest and tires are at its limit of adhesion. Beyond this angle, there is slip and stress put on the tires. 


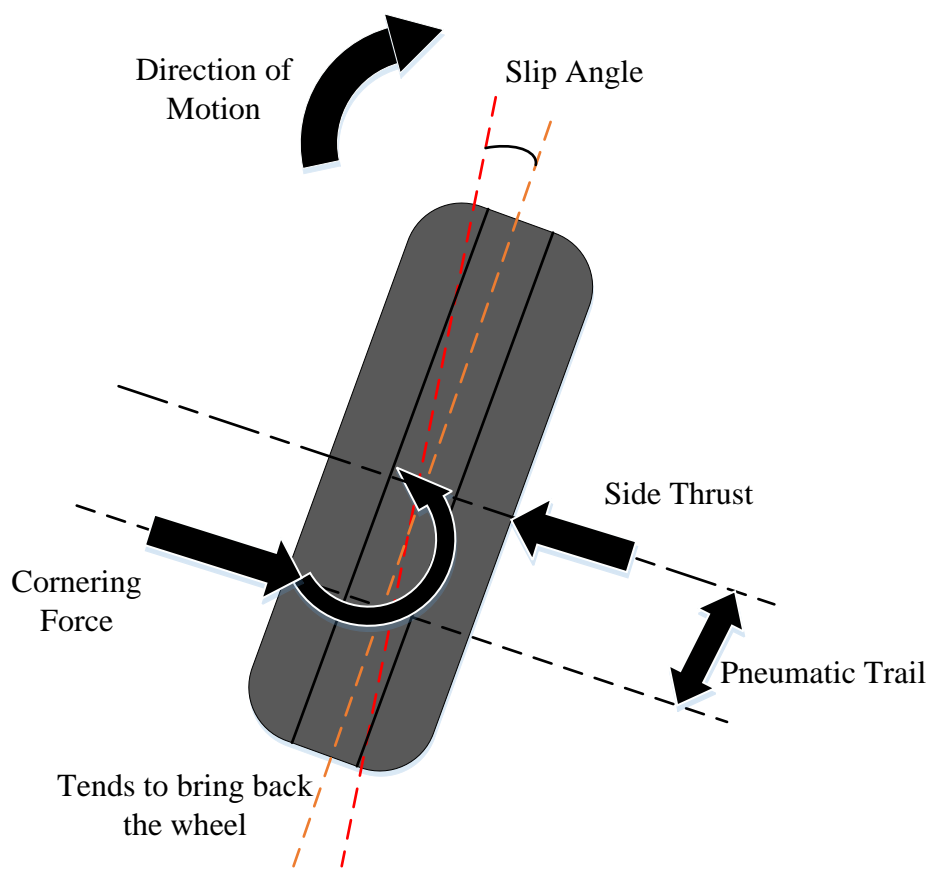

Figure 9: Cornering force 


\section{MATHEMATICAL MODEL}

\subsection{PROBLEM STATEMENT}

A single vendor-buyer coordinated supply chain model is developed. Demand $D$ is assumed to be constant and deterministic. A stochastic lead time is assumed which is exponentially distributed. Because of stochastic lead time, shortage may occur and the shortage cost per unit item per unit time is $\rho_{\text {short, }}$ which is paid by buyer. In this $(Q, r)$ policy, buyer places an order for $Q$ quantity to the vendor as soon as on-hand inventory level drops to re-order level $r$. For each order buyer pays a fixed setup $\operatorname{cost} \vartheta_{b}$. Vendor produces in lots of size $n Q$ with a production rate $P$ where production rate is greater than demand. Each production run incurs a fixed setup cost $\vartheta_{v}$. The buyer receives the shipment size of $Q$. Buyer generally pays for transportation cost for each shipment. Transportation cost depends on lot size, and energy (Diesel) price uncertainty. The stochastic evolution of the energy (Diesel) price has been modeled by a mean-reverting process. $h_{b}$ and $h_{b}$ are the holding cost at the buyer's and vendor's warehouse respectively and $h_{b}>h_{v}$. The mathematical model is formulated to calculate the expected total cost function of the buyer and vendor. The objective is to determine the \# of shipments within 1 setup of vendor, $n$, optimal lot size, $Q$, and optimal reorder point, $r$. Various transportation parameters will be altered to understand the changes in total cost and shipment policies.

\subsection{BUYER'S EXPECTED COST}

\section{(a) Transportation cost:}

Since, energy (Diesel) price uncertainty effects transportation cost; therefore first a diesel pricing model is developed. Mean reverting processes are widely used in financial market to model commodity prices, such as sugar, oil, electricity, and copper (Clewlow and Strickland, 2000). The logic behind a mean reverting process comes from microeconomics. When commodity price decreases, the demand for that commodity tends to increase, while the production tends to decrease. The opposite will occur when the commodity price increases.

Mean reverting equation to model commodity price (Schwartz and Smith, 2000). Let $\zeta_{t}$ be the diesel price at time $t$.

$$
d \ln \zeta_{t}=\beta\left(\mu-\ln \zeta_{t}\right) \zeta_{t} d t+\sigma \zeta_{t} d w_{t}
$$


Now, substitute $\theta_{t}=\ln \zeta_{t}$ in the above equation. $\theta_{t}$ follows mean reverting process (Schwartz and Smith, 2000).

$$
d \theta_{t}=\beta\left(\mu-\theta_{t}\right) d t+\sigma d w_{t}
$$

In the above stochastic differential equation, $\theta_{t}$ is the natural $\log$ of diesel spot price, $\beta$ is the mean reversion speed, $\sigma$ is the volatility of the process, $\mu$ is the long term mean and dwt is the standard Wiener process. The first term of that equation represents drift rate which depends on the mean reversion speed and difference between current price and long term mean. Positive drift implies that the spot price is less than the long term mean, which results in an upward movement on the spot price to approach the long term mean. Alternatively, negative drift rate indicates that the spot price is greater than the long term mean, as a results current price moves downward to revert long term mean. Mean reversion speed rate influences these up and downward movements. At time $t=0, \theta_{t}$ is normally distributed with mean

$$
E\left(\theta_{t} \mid \theta_{0}\right)=e^{\beta t} \theta_{0}+\mu\left(1-e^{-\beta t}\right)
$$

and variance

$$
\operatorname{Var}\left(\theta_{t} \mid \theta_{0}\right)=\frac{\left(1-e^{-2 \beta t}\right) \sigma^{2}}{2 \beta}
$$

As a result, the diesel price is log-normally distributed with mean

$$
E\left(\theta_{t} \mid \theta_{0}\right)=\exp \left\{e^{-\beta t} \theta_{0}+\mu\left(1-e^{-\beta t}\right)+\frac{\frac{1}{2}\left(1-e^{-2 \beta t}\right) \sigma^{2}}{2 \beta}\right\}
$$

As the time $t$ goes to infinity $(t \rightarrow \infty)$, the terms $e^{-\beta t}$ and $e^{-2 \beta t}$ approach to zero. Hence $E\left(\theta_{\infty} \mid \theta_{0}\right)=e^{\left(\mu+\frac{\sigma}{4 \beta}\right)}$. The diesel price from Jan. 3, 2012 to May, 7, 2016 is presented in Figure 10. 


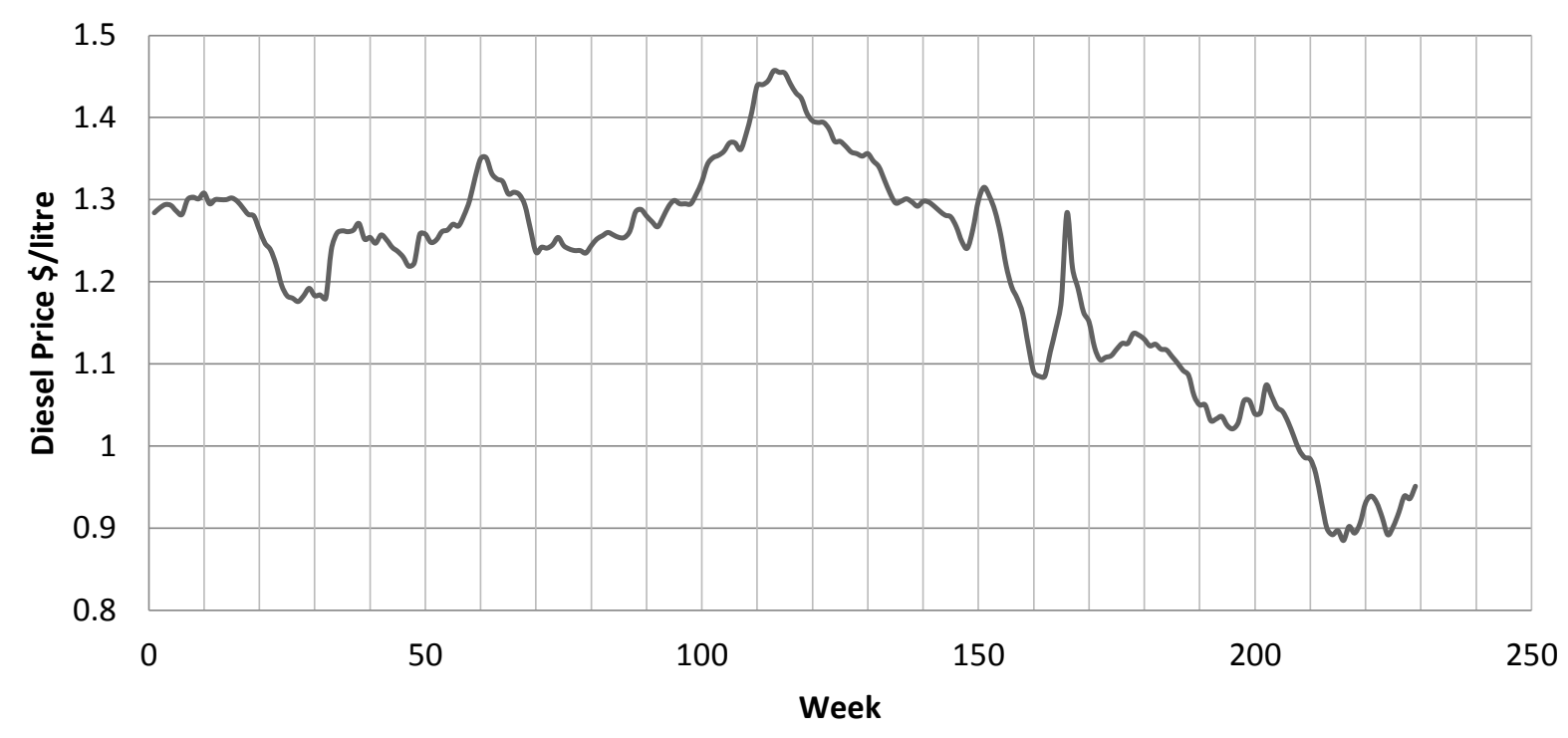

Figure 10: Diesel price historically from Jan. 3, 2012 to May 7, 2016

this shows that the diesel price (per litre) varies between $\$ 0.89$ and $\$ 1.44$. Using this date the estimated values of $\mu, \sigma, \beta$ are $-0.0789,0.09877$, and 0.06929 respectively.

For the first time, transportation cost was addressed into inventory model by adding a fixed cost for unit shipment (Baumol and Vinod, 1970). This implies that the transportation cost does not depend on the size of shipment. Then another model where transportation cost increases in a step function format according to the shipment size was introduced (Lee, 1986). But in this report, transportation cost depends on shipment size, and also depends on diesel price. The transportation cost can be determined by calculating fuel (Diesel) consumption rate during the shipment. The fuel consumption rate can be affected by several factors such as: distance between the buyer and vendor, basis weight of the vehicle, actual weight of vehicle (including the weight of lot size with product, vehicle type, vehicle condition, and vehicle age. Per litre diesel price can be calculated using $e^{\left(\mu+\frac{\sigma}{4 \beta}\right)}$. This is then combined with $U$ (energy) calculated based on literature review.

$$
\begin{gathered}
U(Q)=\left[m g \sin \theta d_{g}+C_{i} M_{f r} s a d_{i}+C_{r} m g \cos \theta \Phi_{t} d_{r} \lambda_{s}+0.5 \rho A_{f} C_{d} v_{r}^{2} s d_{a}\right. \\
\left.+\left(\frac{m^{2} v^{4}}{R^{2} C_{a v}}\right) s \lambda_{s} d_{c}\right]\left(\frac{1}{\eta_{\text {motor }}} e_{v}\right)
\end{gathered}
$$

where $m$ will be divided into three different weights: 
$m=m_{\text {empty }}+m_{\text {trailer }}+m_{p} Q$

$m_{\text {empty }}=$ truck weight only

$m_{\text {trailer }}=$ trailer weight only

$m_{p} Q=$ each product weight multiply by Quantity

$$
\text { Total transportation cost }=e^{\mu+\frac{\sigma}{4 \beta}}\left(\frac{U}{\alpha}\right)
$$

where $\alpha$ is $38.6 \mathrm{MJ} /$ litre

\section{(b) Holding and shortage cost:}

Exponentially distributed lead time is assumed and the probability density function of lead time is defined as,

$$
f_{Y}(y)=\tau e^{-\tau y}, \quad 0<y<\infty
$$

Due to stochastic lead time, different cases may be occurred during buyer's cycle time, such as:

(a) Delivery may arrive before finishing the on-hand inventory level $(\mathrm{Y} \leq \mathrm{r} / \mathrm{D})$

(b) Delivery may arrive after finishing the inventory; in this case short-ages may occur due to longer lead time $(r / D \leq Y \leq(r+Q) / D)$

(c) Delivery may arrive after the cycle time $((\mathrm{r}+\mathrm{Q}) / \mathrm{D}<\mathrm{Y} \leq \infty)$

Depending on these cases, the holding and shortage cost per unit time for buyer is formulated by the following equation:

$$
\begin{aligned}
H(Q, r)_{b}=h_{b} & \int_{0}^{\frac{r}{D}}\left(\frac{Q}{2}+r-D y\right) f_{Y}(y) d y \\
& +\int_{\frac{r}{D}}^{\frac{r+Q}{D}}\left[\frac{\rho_{\text {short }}(D y-r)^{2}}{2 Q}+\frac{h_{b}(Q+r-D y)^{2}}{2 Q}\right] f_{Y}(y) d y \\
& +\rho_{\text {short }} \int_{\frac{r+Q}{D}}^{\infty}\left(D y-r-\frac{Q}{2}\right) f_{Y}(y) d y
\end{aligned}
$$

Now, substituting $f_{Y}(y)=\tau e^{-\tau y}$ into the above equation and simplifying,

$$
h_{b}\left[r+\frac{Q}{2}-\frac{D}{\tau}\right]+\frac{D^{2}\left(\rho_{\text {short }}+h_{b}\right)}{\tau^{2} Q}\left(e^{-\frac{r \tau}{D}}-e^{-\frac{(r+Q) \tau}{D}}\right)
$$




\section{(c) Setup cost:}

The buyer incurs a fixed cost of $\vartheta_{b}$ per order. Therefore, the buyer's expected total cost per unit time can be written as follows:

$$
\begin{aligned}
T C(Q, r)_{b}= & \frac{\vartheta_{b}}{T}+h_{b}\left[r+\frac{Q}{2}-\frac{D}{\tau}\right]+\frac{D^{2}\left(\rho_{\text {short }}+h_{b}\right)}{\tau^{2} Q}\left(e^{-\frac{r \tau}{D}}-e^{-\frac{(r+Q) \tau}{D}}\right) \\
+ & \frac{1}{T}\left[\left(\frac{U}{\alpha}\right)\left(e^{\mu+\frac{\sigma}{4 \beta}}\right)\right]
\end{aligned}
$$

\subsection{VENDOR'S EXPECTED COST}

Vendor's expected cost per unit time consists of holding cost while inventory builds up during the production run, and setup cost.

\section{(a) Holding cost:}

Holding cost is charged for accumulated inventory level during the production run. The accumulated inventory level during the production run is written as follows:

$$
I_{v}=\left[\left\{n Q\left(\frac{Q}{P}+(n-1) T\right)-\frac{n^{2} Q^{2}}{2 P}\right\}-T[Q+2 Q+\cdots+(n-1) Q]\right]
$$

Vendor incurs a cost $h_{v}$ per unit per unit time for accumulated inventory. $n$ is the \# of shipments, $P$ is the production rate, $Q$ is quantity. Therefore, the total holding cost is expressed as:

$$
H(Q, n)_{v}=\frac{h_{v} Q^{2}}{T}\left[\frac{1}{P}\left(1-\frac{n}{2}\right)+\frac{1}{2 D}(n-1)\right]
$$

\section{(b) Set-up cost:}

Vendor incurs a fixed setup cost of $\frac{\vartheta_{v}}{n}$ per buyer's cycle. Therefore, vendor's expected total cost per unit time is given by:

$$
T C(Q, n)_{v}=\frac{h_{v} Q^{2}}{T}\left[\frac{1}{P}\left(1-\frac{n}{2}\right)+\frac{1}{2 D}(n-1)\right]+\frac{\vartheta_{v}}{n T}
$$

\subsection{EXPECTED TOTAL COST PER UNIT TIME}

The total expected cost per unit time for the coordinated vendor- buyer supply chain is the combination of the buyer and the vendor cost per unit time, which is given by:

$$
T C(Q, r, n)=T C(Q, r)_{b}+T C(Q, n)_{v}
$$


Using Equation (22) the optimal number of shipment per vendor setup $n^{*}$, optimal order quantity $Q^{*}$, and optimal reorder level $r^{*}$ is determined.

The value of $T C(Q, r)_{b}$ and $T C(Q, n)_{v}$ can be found from the Equations (18) and (21) respectively. After rearranging these two equations and substituting $T=Q / D$, the following expected total cost is determined:

$$
\begin{aligned}
T C(Q, r, n)= & \frac{D}{Q}\left(\vartheta_{b}+\frac{\vartheta_{v}}{n}\right)+0.5 h_{v} Q(n-1)+\frac{h_{v} Q D}{P}(1-.5 n)+h_{b}\left(r+.5 Q-\frac{D}{\tau}\right) \\
& +D^{2}\left(\rho_{\text {short }}+h_{b}\right) \frac{\exp \left(-\frac{r \tau}{D}\right)-\exp \left(-\frac{(r+Q) \tau}{D}\right)}{\tau^{2} Q} \\
& +\frac{D}{Q} \exp \left(\mu+\frac{\sigma^{2}}{4 \beta}\right) \frac{U}{\alpha}
\end{aligned}
$$

Now, taking the partial derivative of $\operatorname{TC}(Q, r, n)$ with respect to $n$ and set it as zero,

$$
\frac{d T C(Q, r, n)}{d n}=-\frac{D \vartheta_{v}}{n^{2} Q}+0.5 h_{v} Q-\frac{0.5 h_{v} Q D}{P}=0
$$

Rearranging Equation (24), the following expression for optimal $n$ is determined:

$$
n^{*}\left(n^{*}-1\right) \leq \frac{2 D \vartheta_{v}}{h_{v} Q^{2}\left(1-\frac{D}{P}\right)} \leq n^{*}\left(n^{*}+1\right)
$$

Next, take the partial derivative of $\operatorname{TC}(Q, r, n)$ with respect to $r$ and set it as zero,

$$
h_{b}+\frac{D^{2}\left(\rho_{\text {short }}+h_{b}\right)\left(-\frac{\tau e^{-\frac{r \tau}{D}}}{D}+\frac{\tau e^{-\frac{(r+Q) \tau}{D}}}{D}\right)}{\tau^{2} Q}=0
$$

After simplifying the above equation, $r$ variable is isolated:

$$
r=\frac{D}{\tau} \ln \left[\frac{D\left(\rho_{\text {short }}+h_{b}\right)\left(1-e^{\left.-\frac{Q \tau}{D}\right)}\right.}{h_{b} \tau Q}\right]
$$

Now, substituting the value of $r$ in $T C(Q, r, n)$ Equation (23) and take partial derivative with respect to $Q$ : 


$$
\begin{aligned}
& -\frac{D\left(\vartheta_{b}+\frac{\vartheta_{v}}{n}\right)}{Q^{2}}+0.5 h_{v}(n-1)+\frac{h_{v} D(1-0.5 n)}{P} \\
& -\frac{\left(\left(\left((D-0.5 \tau Q) h_{b}+(D-0.5 \tau) \rho_{\text {short }}\right) e^{\frac{\tau Q}{D}}+(-0.5 \tau Q-D) h_{b}+(-0.5 \tau Q-D) \rho_{\text {short }}\right) h_{b}\left(\left(\rho_{\text {short }}+h_{b}\right) e^{\frac{\tau Q}{D}}-h_{b}-\rho_{\text {short }}\right)\right)}{\tau\left(e^{\frac{\tau Q}{D}}-1\right)^{2}\left(\rho_{\text {short }}+h_{b}\right)^{2} Q}
\end{aligned}
$$

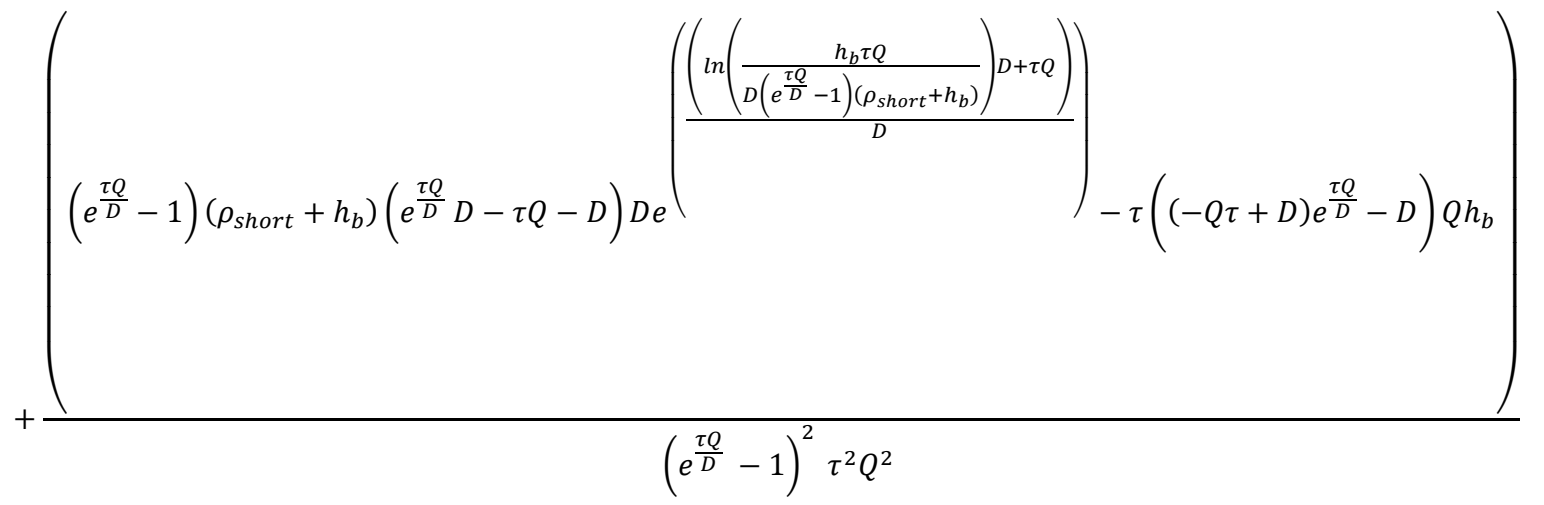

$$
\begin{aligned}
& -\frac{D^{2}\left(\rho_{\text {short }}+h_{b}\right)\left(e^{\left.\frac{\ln \left(\frac{h_{b} \tau Q}{D\left(e^{\frac{\tau Q}{D}}-1\right)\left(\rho_{\text {short }}+h_{b}\right)}\right) D+\tau Q}{D}-\frac{h_{b} \tau Q}{D\left(e^{\frac{\tau Q}{D}}-1\right)\left(\rho_{\text {short }}+h_{b}\right)}\right)}\right.}{\tau^{2 Q^{2}}} \\
& -\left(\frac{1}{1000000}\right)\left(\frac{1}{Q^{2} e t a_{\text {motor }} \alpha}\right)\left(D e ^ { \mu + ( \frac { 1 } { 4 } ) ( \frac { \sigma ^ { 2 } } { \beta } ) } \left(\left(Q m_{p}+m_{\text {empty }}+m_{\text {trailer }}\right) g \sin \left(\left(\frac{1}{180}\right) \theta \pi\right) d_{g}+C_{i} M_{f r} s a d_{i}\right.\right. \\
& \left.\left.+C_{r}\left(Q m_{p}+m_{\text {empty }}+m_{\text {trailer }}\right) g \cos \left(\left(\frac{1}{180}\right) \theta \pi\right) \Phi_{t} d_{r} \lambda_{s}+0.5 \rho_{\text {air }} A_{f} C_{d} v_{r}^{2} s d_{a}+\frac{\left(Q m_{p}+m_{\text {empty }}+m_{\text {trailer }}\right)^{2} v^{4} s \lambda_{s} d_{c}}{C_{a v} R^{2}}\right) e_{v}\right) \\
& \left(\frac{1}{1000000}\right) \frac{D e^{\mu+\left(\frac{1}{4}\right)\left(\frac{\sigma^{2}}{\beta}\right)}\left(m_{p} g \sin \left(\left(\frac{1}{180}\right) \theta \pi\right) d_{g}+C_{r} m_{p} g \cos \left(\left(\frac{1}{180}\right) \theta \pi\right) \Phi_{t} d_{r} \lambda_{s}+\frac{\left(2\left(Q m_{p}+m_{\text {empty }}+m_{\text {trailer }}\right)\right) v^{4} s \lambda_{s} d_{c} m_{p}}{C_{a v} R^{2}}\right) e_{v}}{Q e t a^{2}}
\end{aligned}
$$


NOTE: Equation (28) shows a few numerical values

$\frac{1}{180} \quad$ Converting slope from Degrees to Radians

$\frac{1}{1000000}$ Converting energy from Joules to Mega Joules

The algorithm below is used to determine the optimal $Q, r, n$ values:

Step 0: Set $n=1$

Step 1: Find out optimal value of $Q$ from Equation (28) for the set $n$ value

Step 2: Compute the value of $r$ using Equation (27)

Step 3: If the optimality conditions given in Equation (25) is satisfied for $Q, n$ then move to Step 4, else go to Step 5.

Step 4: If $n=1$ then make sure $n=2$ total cost using Equation (23) is higher than when $n=1$ else $n=1$ is not an optimal solution. Choose $n=n^{*}, Q=Q^{*}, r=r^{*}$ and compute expected total cost per unit time from Equation (23).

Step 5: Increment $n$ by 1 and go to Step 2 . 


\section{NUMERICAL EXAMPLE}

In this section of the report, consider the following data and let's implement the model developed in the previous section. Products transported from Toronto to Vancouver. Assume that the distance traveling is constant on highway; hence acceleration/deceleration is negligible.

Let production rate, $P=20000$ units/year, demand rate, $D=10000$ units/year, holding cost for vendor, $h_{v}=\$ 4 /$ unit/year, setup cost for vendor, $\vartheta_{v}=\$ 1500 /$ cycle, order cost for buyer, $\vartheta_{b}=$ $\$ 100 /$ order, holding cost for buyer, $h_{b}=\$ 5 /$ unit/year, shortage cost, $\rho_{\text {short }}=\$ 200 /$ unit/year, lead time $=3$ weeks. Mean reversion speed, $\beta=0.06929$, long term mean, $\mu=-0.0789$, volatility of the process, $\sigma=0.09877$, energy per litre of diesel, $\alpha=35.86 \mathrm{MJ} / \mathrm{L}$.

Let truck energy MJ be calculated using the following data (Ehsani and Fadai, 2016):

Gravity, $g=9.81 \mathrm{~m} / \mathrm{s}^{2}$, road gradient, $\theta=0.1$, distance travelled for the external forces (gravitational), $d_{g}=4300 \mathrm{~km}$, rolling resistance, $C_{r}=0.018$, truck weight, $m_{\text {empty }}=9071 \mathrm{~kg}$, empty trailer weight, $m_{\text {trailer }}=6351 \mathrm{~kg}$, weight of each product, $m_{p}=15$, temperature factor effects of rolling and tires resistance, $\Phi_{t}=1$, distance travelled with rolling resistance, $d_{r}=4300$ $\mathrm{km}$, pavement effects on rolling and tires resistance, $\lambda_{s}=0.29$, density of air, $\rho_{\text {air }}=$ $101325 /\left(287.058^{*}(273+T)\right)$ where $T$ is temperature, $\mathrm{T}=15^{\circ} \mathrm{C}$ frontal area of truck, $A_{f}=7.92$ $\mathrm{m}^{2}$, aerodynamic resistance coefficient, $C_{d}=0.61$, relative vehicle speed with wind effect, $v_{r}=$ $27.7 \mathrm{~m} / \mathrm{s}$, distance traveled with aerodynamic resistance, $d_{a}=4300 \mathrm{~km}$, vehicle speed on curve, $v=5.5 \mathrm{~m} / \mathrm{s}$, path radius from center of gravity, $R=200 \mathrm{~m}$, cornering stiffness, $C_{a v}=120$ $\mathrm{kN} / \mathrm{rad}$, distance traveled when turning or on ramp, $d_{c}=1500 \mathrm{~m}$, truck engine efficiency, $\eta_{\text {motor }}=0.4$, wind exposure, $e_{v}=1$. $\mathrm{CO}^{2}$ produced per litre of diesel burnt is $5.92 \mathrm{lbs}$. Using the algorithm in mathematical model section, the following answers are calculated:

Step 0: $\quad n=1$

Step 1: $\quad$ Substitute values in Equation (28) and solve for $Q$.

$Q=3126.57$

Step 2: $\quad$ Solve for $r$ using Equation (27)

$r=1160.16$

Step 3: $\quad$ Using Equation (25) it is found that optimality condition is met. 
$0<1.53446<2$

Step 4: $\quad$ Total cost using Equation (23) is $\$ 27923.2$ but this is with $n=1$ so iteration with $n=2$ needs to be done to make sure this is the most optimal solution.

Step 5: $\quad$ Change $n$ to 2

Repeat Step 1: $\quad$ Substitute values in Equation (28) and solve for $Q$.

$Q=2317.50$

Repeat Step 2: $\quad$ Solve for $r$ using Equation (27)

$r=1324.62$

Repeat Step 3: Using Equation (25) it is found that optimality condition is met.

$2<2.79287<6$

Repeat Step 4: Now it can be checked if $n=1$ is optimal solution or $n=2$ is optimal solution.

Substitute $Q, n, r$ values in Equation (23) and total cost is $\$ 27838.5$

This confirms that optimal solution is not with $n=1$ but rather with $n=2$

If $n=3$ then Equation (28) gives $Q=1924.42$, Equation (27) gives $r=1421.24$ but Equation (25) optimality condition is not met $6<4.05033<12$. Hence $n=3$ cannot be the optimal solution.

Table 8: Optimal $Q, n, r$ and Total Cost values for example

\begin{tabular}{|c|c|c|c|c|c|c|}
\hline Demand & Production Rate & Lead time & $\boldsymbol{n}$ & \multicolumn{2}{|c|}{ Quantity (units) } & Reorder Point \\
\hline 10,000 & 20,000 & 21 & 2 & \multicolumn{2}{|c|}{2317.50} & 1324.62 \\
\hline $\begin{array}{c}\text { Order \& } \\
\text { Setup cost }\end{array}$ & $\begin{array}{c}\text { Vendor } \\
\text { Holding Cost }\end{array}$ & $\begin{array}{l}\text { Buyer holding and } \\
\text { shortage cost }\end{array}$ & & tation & Total & $\begin{array}{c}\mathrm{CO}_{2} \text { Emission } \\
(\mathrm{lbs})\end{array}$ \\
\hline$\$ 3,667.74$ & $\$ 4,635.01$ & $\$ 12,416.90$ & & 3.91 & $\$ 27,8$ & $44,007.68$ \\
\hline
\end{tabular}

From the results it is evident that two big costs impacting total cost is buyer's holding cost, shortage cost and transportation cost. The transportation cost will always be opposite to buyers holding and shortage cost. This is evident in the results throughout the report. The table below shows how the lead time makes a difference in overall cost. 
Table 9: Production rate 20000, different lead times

\begin{tabular}{|c|c|c|c|c|c|c|c|c|c|}
\hline $\begin{array}{c}\text { Lead } \\
\text { time }\end{array}$ & $n$ & $Q$ & $\begin{array}{c}\text { Reorder } \\
\text { Point }\end{array}$ & $\begin{array}{c}\text { Order \& } \\
\text { Setup cost }\end{array}$ & $\begin{array}{c}\text { Vendor } \\
\text { Holding } \\
\text { Cost }\end{array}$ & $\begin{array}{c}\text { Buyer } \\
\text { holding \& } \\
\text { shortage } \\
\text { cost }\end{array}$ & $\begin{array}{c}\text { Transportation } \\
\text { cost }\end{array}$ & Total cost & $\begin{array}{c}\mathrm{CO}_{2} \\
\text { Emission } \\
(\text { lbs })\end{array}$ \\
\hline 7 & 2 & 2109.38 & 252.34 & $\$ 4,029.62$ & $\$ 4,218.76$ & $\$ 6,535.13$ & $\$ 7,523.16$ & $\$ 22,306.70$ & $46,506.63$ \\
\hline 14 & 2 & 2219.91 & 749.78 & $\$ 3,828.99$ & $\$ 4,439.82$ & $\$ 9,298.67$ & $\$ 7,298.98$ & $\$ 24,866.40$ & $45,120.76$ \\
\hline 21 & 2 & 2317.50 & 1324.62 & $\$ 3,667.74$ & $\$ 4,635.01$ & $\$ 12,416.90$ & $\$ 7,118.91$ & $\$ 27,838.50$ & $44,007.68$ \\
\hline 28 & 1 & 3257.93 & 1728.30 & $\$ 4,911.09$ & $\$ 3,257.93$ & $\$ 16,786.30$ & $\$ 5,940.41$ & $\$ 30,895.80$ & $36,722.36$ \\
\hline 35 & 1 & 3374.47 & 2325.63 & $\$ 4,741.49$ & $\$ 3,374.47$ & $\$ 20,064.30$ & $\$ 5,840.57$ & $\$ 34,020.80$ & $36,105.18$ \\
\hline 42 & 1 & 3477.04 & 2943.23 & $\$ 4,601.62$ & $\$ 3,477.04$ & $\$ 23,408.70$ & $\$ 5,758.31$ & $\$ 37,245.70$ & $35,596.67$ \\
\hline
\end{tabular}

Table 9 shows that as lead time increases the \# of shipment changes from 2 to 1 and quantity/reorder point also increases. As product takes longer to reach buyer, it is critical that buyer gets more quantity and reorders in timely manner. But there is a down side to this because that increases the buyer holding and shortage cost. Transportation cost decreases because more quantity is shipped in less \# of shipments. Although $Q$ is high which would increase the transportation cost, but when \# of shipment changes from 2 to 1 it is evident that overall cost is lower. But shipment is at 2 and $Q$ increases, it can be seen that transportation cost increases because the weight in trailer increases due to more products which leads to more fuel consumption hence higher transportation cost. Total cost changes significantly from $\$ 22,306.70$ to $\$ 37,245.70$, a $167 \%$ increase in cost and this shows the importance of keeping the lead time to as low as possible. Now let's compare different production rates. 
Table 10: Varying production rate and lead time vs total cost

\begin{tabular}{|c|c|c|c|c|c|c|c|c|c|c|}
\hline $\begin{array}{l}\text { Production } \\
\text { Rate }\end{array}$ & $\begin{array}{l}\text { Lead } \\
\text { time }\end{array}$ & $n$ & $Q$ & $\begin{array}{l}\text { Reorder } \\
\text { Point }\end{array}$ & $\begin{array}{c}\text { Order \& } \\
\text { Setup cost }\end{array}$ & $\begin{array}{l}\text { Vendor } \\
\text { Holding } \\
\text { Cost }\end{array}$ & $\begin{array}{l}\text { Buyer holding } \\
\& \text { shortage } \\
\text { cost }\end{array}$ & $\begin{array}{c}\text { Transportation } \\
\text { cost }\end{array}$ & Total cost & $\begin{array}{c}\mathrm{CO}_{2} \\
\text { Emission } \\
\quad(\mathrm{lbs})\end{array}$ \\
\hline \multirow{6}{*}{15000} & 7 & 2 & 2109.38 & 252.34 & $\$ 4,029.62$ & $\$ 4,218.76$ & $\$ 6,535.13$ & $\$ 7,523.16$ & $\$ 22,306.70$ & $46,506.63$ \\
\hline & 14 & 2 & 2219.91 & 749.78 & $\$ 3,828.99$ & $\$ 4,439.82$ & $\$ 9,298.67$ & $\$ 7,298.98$ & $\$ 24,866.40$ & $45,120.76$ \\
\hline & 21 & 2 & 2317.50 & 1324.62 & $\$ 3,667.74$ & $\$ 4,635.01$ & $\$ 12,416.90$ & $\$ 7,118.91$ & $\$ 27,838.50$ & $44,007.68$ \\
\hline & 28 & 2 & 2397.13 & 1940.25 & $\$ 3,545.91$ & $\$ 4,794.26$ & $\$ 15,694.10$ & $\$ 6,982.94$ & $\$ 31,017.20$ & $43,167.09$ \\
\hline & 35 & 1 & 3180.44 & 2375.82 & $\$ 5,030.75$ & $\$ 4,240.59$ & $\$ 19,830.20$ & $\$ 6,010.90$ & $\$ 35,112.50$ & $37,158.18$ \\
\hline & 42 & 1 & 3266.49 & 3003.21 & $\$ 4,898.22$ & $\$ 4,355.32$ & $\$ 23,182.30$ & $\$ 5,932.83$ & $\$ 38,368.60$ & $36,675.53$ \\
\hline \multirow{6}{*}{17500} & 7 & 2 & 2109.38 & 252.34 & $\$ 4,029.62$ & $\$ 4,218.76$ & $\$ 6,535.13$ & $\$ 7,523.16$ & $\$ 22,306.70$ & $46,506.63$ \\
\hline & 14 & 2 & 2219.91 & 749.78 & $\$ 3,828.99$ & $\$ 4,439.82$ & $\$ 9,298.67$ & $\$ 7,298.98$ & $\$ 24,866.40$ & $45,120.76$ \\
\hline & 21 & 2 & 2317.50 & 1324.62 & $\$ 3,667.74$ & $\$ 4,635.01$ & $\$ 12,416.90$ & $\$ 7,118.91$ & $\$ 27,838.50$ & $44,007.68$ \\
\hline & 28 & 2 & 2397.13 & 1940.25 & $\$ 3,545.91$ & $\$ 4,794.26$ & $\$ 15,694.10$ & $\$ 6,982.94$ & $\$ 31,017.20$ & $43,167.09$ \\
\hline & 35 & 1 & 3287.54 & 2347.87 & $\$ 4,866.87$ & $\$ 3,757.18$ & $\$ 19,958.20$ & $\$ 5,914.36$ & $\$ 34,496.60$ & $36,561.36$ \\
\hline & 42 & 1 & 3382.53 & 2969.88 & $\$ 4,730.18$ & $\$ 3,865.75$ & $\$ 23,305.70$ & $\$ 5,833.91$ & $\$ 37,735.60$ & $36,064.06$ \\
\hline \multirow{6}{*}{20000} & 7 & 2 & 2109.38 & 252.34 & $\$ 4,029.62$ & $\$ 4,218.76$ & $\$ 6,535.13$ & $\$ 7,523.16$ & $\$ 22,306.70$ & $46,506.63$ \\
\hline & 14 & 2 & 2219.91 & 749.78 & $\$ 3,828.99$ & $\$ 4,439.82$ & $\$ 9,298.67$ & $\$ 7,298.98$ & $\$ 24,866.40$ & $45,120.76$ \\
\hline & 21 & 2 & 2317.50 & 1324.62 & $\$ 3,667.74$ & $\$ 4,635.01$ & $\$ 12,416.90$ & $\$ 7,118.91$ & $\$ 27,838.50$ & $44,007.68$ \\
\hline & 28 & 1 & 3257.93 & 1728.30 & $\$ 4,911.09$ & $\$ 3,257.93$ & $\$ 16,786.30$ & $\$ 5,940.41$ & $\$ 30,895.80$ & $36,722.36$ \\
\hline & 35 & 1 & 3374.47 & 2325.63 & $\$ 4,741.49$ & $\$ 3,374.47$ & $\$ 20,064.30$ & $\$ 5,840.57$ & $\$ 34,020.80$ & $36,105.18$ \\
\hline & 42 & 1 & 3477.04 & 2943.23 & $\$ 4,601.62$ & $\$ 3,477.04$ & $\$ 23,408.70$ & $\$ 5,758.31$ & $\$ 37,245.70$ & $35,596.67$ \\
\hline \multirow{6}{*}{25000} & 7 & 2 & 2109.38 & 252.34 & $\$ 4,029.62$ & $\$ 4,218.76$ & $\$ 6,535.13$ & $\$ 7,523.16$ & $\$ 22,306.70$ & $46,506.63$ \\
\hline & 14 & 1 & 3081.29 & 625.07 & $\$ 5,192.62$ & $\$ 2,465.04$ & $\$ 10,828.60$ & $\$ 6,106.35$ & $\$ 24,592.60$ & $37,748.21$ \\
\hline & 21 & 1 & 3235.35 & 1140.92 & $\$ 4,945.36$ & $\$ 2,588.28$ & $\$ 13,793.00$ & $\$ 5,960.59$ & $\$ 27,287.20$ & $36,847.16$ \\
\hline & 28 & 1 & 3378.43 & 1702.05 & $\$ 4,735.93$ & $\$ 2,702.74$ & $\$ 16,956.30$ & $\$ 5,837.29$ & $\$ 30,232.30$ & $36,084.97$ \\
\hline & 35 & 1 & 3507.08 & 2292.44 & $\$ 4,562.20$ & $\$ 2,805.66$ & $\$ 20,229.90$ & $\$ 5,735.14$ & $\$ 33,332.90$ & $35,453.46$ \\
\hline & 42 & 1 & 3621.72 & 2903.26 & $\$ 4,417.79$ & $\$ 2,897.37$ & $\$ 23,570.60$ & $\$ 5,650.32$ & $\$ 36,536.10$ & $34,929.15$ \\
\hline
\end{tabular}


Table 10 is very insightful because it can be clearly seen that at small lead time like 7 days even if the production rate increases, there is no difference in total cost. But as the lead time increases and production rate increases, the number of shipments $(n)$ starts changing from 2 to 1 . At certain point in each production rate, it makes more financial sense to ship more quantity in less \# of shipments because holding and shortage costs it outweighed by order, setup cost, vendor holding cost and transportation cost as seen in Table 11.

Table 11: Production rate 20,000 but different $\boldsymbol{n}$ values

\begin{tabular}{|c|c|c|c|c|c|c|c|c|}
\hline $\begin{array}{c}\text { Lead } \\
\text { time }\end{array}$ & $n$ & $Q$ & $\begin{array}{c}\text { Reorder } \\
\text { Point }\end{array}$ & $\begin{array}{c}\text { Order \& } \\
\text { Setup cost }\end{array}$ & $\begin{array}{c}\text { Vendor } \\
\text { Holding } \\
\text { Cost }\end{array}$ & $\begin{array}{c}\text { Buyer holding } \\
\& \text { shortage cost }\end{array}$ & $\begin{array}{c}\text { Transportation } \\
\text { cost }\end{array}$ & Total cost \\
\hline 28 & 1 & 3257.93 & 1728.30 & $\$ 4,911.09$ & $\$ 3,257.93$ & $\$ 16,786.30$ & $\$ 5,940.41$ & $\$ 30,895.80$ \\
\hline 28 & 2 & 2397.13 & 1940.25 & $\$ 3,545.91$ & $\$ 4,794.26$ & $\$ 15,694.10$ & $\$ 6,982.94$ & $\$ 31,017.20$ \\
\hline
\end{tabular}

Now the results show the impact of production rate, lead time on $Q, n, r$ and various costs associated to supply chain. It is clear that buyer holding, storage cost and transpiration cost takes up a big chunk of the total cost. It is critical to lower buyer holding and shortage cost to minimize total cost. But there are various factors which lead up to high transportation cost. The report will now analyze some factors that impact the transportation cost. As seen in literature review that the biggest impact on transportation cost comes from truck engine efficiency, road gradient, truck features like aerodynamics of the truck, weather, product weight, distance and of course driving style of the driver. Taking the same example as used thus far, let's change some parameters to understand impact on transportation cost.

Table 12: Impact of truck engine efficiency on total cost

\begin{tabular}{|c|c|c|c|c|c|c|c|c|c|}
\hline & & & $Q$ & $\begin{array}{c}\text { Reorder } \\
\text { Point }\end{array}$ & $\begin{array}{c}\text { Order \& } \\
\text { Setup } \\
\text { cost }\end{array}$ & $\begin{array}{c}\text { Vendor } \\
\text { Holding } \\
\text { Cost }\end{array}$ & $\begin{array}{c}\text { Buyer } \\
\text { holding \& } \\
\text { shortage } \\
\text { cost }\end{array}$ & $\begin{array}{c}\text { Transportation } \\
\text { cost }\end{array}$ & $\begin{array}{c}\text { Total cost } \\
\text { Emission } \\
(\mathrm{lbs})\end{array}$ \\
\hline $\mathbf{0 . 3 6}$ & 1 & 3181.57 & 1150.36 & $\$ 5,028.97$ & $\$ 3,181.57$ & $\$ 13,705.70$ & $\$ 6,677.62$ & $\$ 28,593.90$ & $41,279.65$ \\
\hline $\mathbf{0 . 3 8}$ & 2 & 2345.67 & 1318.17 & $\$ 3,623.70$ & $\$ 4,691.34$ & $\$ 12,455.00$ & $\$ 7,441.85$ & $\$ 28,211.90$ & $46,003.93$ \\
\hline $\mathbf{0 . 4}$ & 2 & 2317.50 & 1324.62 & $\$ 3,667.74$ & $\$ 4,635.01$ & $\$ 12,416.90$ & $\$ 7,118.91$ & $\$ 27,838.50$ & $44,007.68$ \\
\hline $\mathbf{0 . 4 2}$ & 2 & 2291.65 & 1330.60 & $\$ 3,709.12$ & $\$ 4,583.29$ & $\$ 12,382.10$ & $\$ 6,823.92$ & $\$ 27,498.50$ & $42,184.09$ \\
\hline $\mathbf{0 . 4 4}$ & 2 & 2267.82 & 1336.15 & $\$ 3,748.09$ & $\$ 4,535.64$ & $\$ 12,350.30$ & $\$ 6,553.30$ & $\$ 27,187.30$ & $40,511.20$ \\
\hline
\end{tabular}

Table 12 shows that as engine efficiency decreases, the total cost increases. Number of shipment ( $n$ ) changes from 2 to 1 when engine is $36 \%$ efficient because cost of transportation increases significantly. 
Table 13: Road gradient impact on transportation cost

\begin{tabular}{|c|c|c|c|c|c|c|c|c|c|}
\hline$\theta$ & $n$ & $Q$ & $\begin{array}{c}\text { Reorder } \\
\text { Point }\end{array}$ & $\begin{array}{c}\text { Order \& } \\
\text { Setup } \\
\text { cost }\end{array}$ & $\begin{array}{c}\text { Vendor } \\
\text { Holding } \\
\text { Cost }\end{array}$ & $\begin{array}{c}\text { Buyer } \\
\text { holding \& } \\
\text { shortage } \\
\text { cost }\end{array}$ & $\begin{array}{c}\text { Transportation } \\
\text { cost }\end{array}$ & Total cost & $\begin{array}{c}\mathrm{CO}_{2} \\
\text { Emission } \\
(\mathrm{lbs})\end{array}$ \\
\hline 0 & 2 & 2273.95 & 1334.72 & $\$ 3,738.00$ & $\$ 4,547.89$ & $\$ 12,358.50$ & $\$ 6,127.16$ & $\$ 26,771.50$ & $37,876.90$ \\
\hline 0.1 & 2 & 2317.50 & 1324.62 & $\$ 3,667.74$ & $\$ 4,635.01$ & $\$ 12,416.90$ & $\$ 7,118.91$ & $\$ 27,838.50$ & $44,007.68$ \\
\hline 0.2 & 2 & 2360.09 & 1314.89 & $\$ 3,601.56$ & $\$ 4,720.17$ & $\$ 12,474.70$ & $\$ 8,103.07$ & $\$ 28,899.50$ & $50,091.52$ \\
\hline 0.3 & 1 & 3205.75 & 1146.10 & $\$ 4,991.02$ & $\$ 3,205.75$ & $\$ 13,744.90$ & $\$ 7,934.13$ & $\$ 29,875.80$ & $49,047.18$ \\
\hline 0.4 & 1 & 3244.48 & 1139.33 & $\$ 4,931.45$ & $\$ 3,244.48$ & $\$ 13,807.90$ & $\$ 8,863.86$ & $\$ 30,847.70$ & $54,794.39$ \\
\hline
\end{tabular}

Table 13 reflects the substantial impact of road gradient on transportation cost. It is critical to know this information when an enterprise is deciding to establish various facilities around the country. If the facility is located in a hilly area where the truck has to go up slope, then supply chain can potentially incur high transportation costs. This is also something to consider when planning routes to transport goods because it may be sometimes worth taking an alternate route to avoid slopes which can incur higher costs.

Table 14: Aerodynamic resistance impact on transportation cost

\begin{tabular}{|c|c|c|c|c|c|c|c|c|c|}
\hline$C_{d}$ & $n$ & $Q$ & $\begin{array}{c}\text { Reorder } \\
\text { Point }\end{array}$ & $\begin{array}{c}\text { Order \& } \\
\text { Setup } \\
\text { cost }\end{array}$ & $\begin{array}{c}\text { Vendor } \\
\text { Holding } \\
\text { Cost }\end{array}$ & $\begin{array}{c}\text { Buyer } \\
\text { holding \& } \\
\text { shortage cost }\end{array}$ & $\begin{array}{c}\text { Transportation } \\
\text { cost }\end{array}$ & Total cost & $\begin{array}{c}\mathrm{CO}_{2} \\
\text { Emission } \\
(\mathrm{lbs})\end{array}$ \\
\hline 0.5 & 2 & 2249.49 & 1340.45 & $\$ 3,778.64$ & $\$ 4,498.97$ & $\$ 12,326.00$ & $\$ 6,720.18$ & $\$ 27,323.80$ & $41,542.80$ \\
\hline 0.55 & 2 & 2280.71 & 1333.14 & $\$ 3,726.91$ & $\$ 4,561.42$ & $\$ 12,367.50$ & $\$ 6,903.84$ & $\$ 27,559.70$ & $42,678.15$ \\
\hline 0.61 & 2 & 2317.50 & 1324.62 & $\$ 3,667.74$ & $\$ 4,635.01$ & $\$ 12,416.90$ & $\$ 7,118.91$ & $\$ 27,838.50$ & $44,007.68$ \\
\hline 0.65 & 2 & 2341.64 & 1319.09 & $\$ 3,629.93$ & $\$ 4,683.28$ & $\$ 12,449.60$ & $\$ 7,259.26$ & $\$ 28,022.00$ & $44,875.23$ \\
\hline 0.7 & 1 & 3177.10 & 1151.15 & $\$ 5,036.04$ & $\$ 3,177.10$ & $\$ 13,698.50$ & $\$ 6,316.74$ & $\$ 28,228.40$ & $39,048.83$ \\
\hline
\end{tabular}

Table 15: Truck frontal area impact on transportation cost

\begin{tabular}{|c|c|c|c|c|c|c|c|c|c|}
\hline$A_{f}$ & $n$ & $Q$ & $\begin{array}{c}\text { Reorder } \\
\text { Point }\end{array}$ & $\begin{array}{c}\text { Order \& } \\
\text { Setup } \\
\text { cost }\end{array}$ & $\begin{array}{c}\text { Vendor } \\
\text { Holding } \\
\text { Cost }\end{array}$ & $\begin{array}{c}\text { Buyer } \\
\text { holding \& } \\
\text { shortage } \\
\text { cost }\end{array}$ & $\begin{array}{c}\text { Transportation } \\
\text { cost }\end{array}$ & Total cost & $\begin{array}{c}\mathrm{CO}_{2} \\
\text { Emission } \\
(\mathrm{lbs})\end{array}$ \\
\hline 6.5 & 2 & 2249.88 & 1340.36 & $\$ 3,777.97$ & $\$ 4,499.77$ & $\$ 12,326.50$ & $\$ 6,722.53$ & $\$ 27,326.80$ & $41,557.31$ \\
\hline 7 & 2 & 2273.97 & 1334.71 & $\$ 3,737.95$ & $\$ 4,547.95$ & $\$ 12,358.50$ & $\$ 6,864.31$ & $\$ 27,508.70$ & $42,433.77$ \\
\hline 7.5 & 2 & 2297.76 & 1329.18 & $\$ 3,699.26$ & $\$ 4,595.51$ & $\$ 12,390.30$ & $\$ 7,003.66$ & $\$ 27,688.70$ & $43,295.15$ \\
\hline 7.92 & 2 & 2317.50 & 1324.62 & $\$ 3,667.74$ & $\$ 4,635.01$ & $\$ 12,416.90$ & $\$ 7,118.91$ & $\$ 27,838.50$ & $44,007.68$ \\
\hline 8.5 & 2 & 2344.44 & 1318.45 & $\$ 3,625.60$ & $\$ 4,688.88$ & $\$ 12,453.40$ & $\$ 7,275.49$ & $\$ 28,043.30$ & $44,975.65$ \\
\hline
\end{tabular}

Table 14 shows that aerodynamics resistance of a truck can make an impact on transportation cost as well. A lot of research has gone into reducing aerodynamics resistance recently. The 
biggest force that truck has to overcome when on the highway is aerodynamics. Many aerodynamic accessories are now available for trucks. It can be seen in Figure 8 the typical parts of tractor trailer which influence aerodynamic resistance. Table 15 shows how less frontal area can reduce transportation costs. Some tests conducted with new accessories reflect in

Table 7. These are all the items that need to be kept in mind when either purchasing a fleet for the company or selection a transportation partner.

Table 16: Temperature $\left({ }^{\circ} \mathrm{C}\right)$ impact on transportation cost

\begin{tabular}{|c|c|c|c|c|c|c|c|c|c|}
\hline$T$ & $n$ & $Q$ & $\begin{array}{c}\text { Reorder } \\
\text { Point }\end{array}$ & $\begin{array}{c}\text { Order \& } \\
\text { Setup } \\
\text { cost }\end{array}$ & $\begin{array}{c}\text { Vendor } \\
\text { Holding } \\
\text { Cost }\end{array}$ & $\begin{array}{c}\text { Buyer } \\
\text { holding \& } \\
\text { shortage cost }\end{array}$ & $\begin{array}{c}\text { Transportation } \\
\text { cost }\end{array}$ & Total cost & $\begin{array}{c}\mathrm{CO}_{2} \\
\text { Emission } \\
\text { (bs) }\end{array}$ \\
\hline-30 & 1 & 3189.84 & 1148.90 & $\$ 5,015.93$ & $\$ 3,189.84$ & $\$ 13,719.10$ & $\$ 6,380.61$ & $\$ 28,305.50$ & $39,443.61$ \\
\hline-20 & 1 & 3173.98 & 1151.70 & $\$ 5,041.00$ & $\$ 3,173.98$ & $\$ 13,693.50$ & $\$ 6,301.06$ & $\$ 28,209.50$ & $38,951.87$ \\
\hline-10 & 2 & 2352.40 & 1316.64 & $\$ 3,613.34$ & $\$ 4,704.79$ & $\$ 12,464.20$ & $\$ 7,321.60$ & $\$ 28,103.90$ & $45,260.64$ \\
\hline 0 & 2 & 2337.75 & 1319.98 & $\$ 3,635.97$ & $\$ 4,675.50$ & $\$ 12,444.30$ & $\$ 7,236.67$ & $\$ 27,992.40$ & $44,735.56$ \\
\hline 10 & 2 & 2324.04 & 1323.12 & $\$ 3,657.43$ & $\$ 4,648.08$ & $\$ 12,425.70$ & $\$ 7,156.96$ & $\$ 27,888.20$ & $44,242.89$ \\
\hline 15 & 2 & 2317.50 & 1324.62 & $\$ 3,667.74$ & $\$ 4,635.01$ & $\$ 12,416.90$ & $\$ 7,118.91$ & $\$ 27,838.50$ & $44,007.68$ \\
\hline 20 & 2 & 2311.17 & 1326.08 & $\$ 3,677.79$ & $\$ 4,622.35$ & $\$ 12,408.30$ & $\$ 7,082.00$ & $\$ 27,790.50$ & $43,779.47$ \\
\hline 25 & 2 & 2305.03 & 1327.50 & $\$ 3,687.58$ & $\$ 4,610.07$ & $\$ 12,400.10$ & $\$ 7,046.17$ & $\$ 27,743.90$ & $43,557.97$ \\
\hline 30 & 2 & 2299.08 & 1328.88 & $\$ 3,697.14$ & $\$ 4,598.15$ & $\$ 12,392.10$ & $\$ 7,011.37$ & $\$ 27,698.70$ & $43,342.87$ \\
\hline
\end{tabular}

Table 16 reflects the impact of temperature on transportation cost. At certain temperature in this example it is financially better to make fewer shipments with more quantity. This is validated when the temperature changes from -10 to $-20{ }^{\circ} \mathrm{C}$. This temperature impacts the density of air which then increases the aerodynamic resistance that the truck has to overcome. This plays an important role in parts of the world where it gets significantly cold. In Canada, temperatures can go down to $-45{ }^{\circ} \mathrm{C}$ in some parts of the country. Again, this is important to keep in mind when establishing facility locations for the company.

Table 17: Product weight impact on transportation cost

\begin{tabular}{|c|c|c|c|c|c|c|c|c|c|}
\hline $\begin{array}{l}m_{p} \\
(\mathrm{~kg})\end{array}$ & $n$ & $Q$ & $\begin{array}{l}\text { Reorder } \\
\text { Point }\end{array}$ & $\begin{array}{c}\text { Order \& } \\
\text { Setup } \\
\text { cost }\end{array}$ & $\begin{array}{l}\text { Vendor } \\
\text { Holding } \\
\text { Cost }\end{array}$ & $\begin{array}{c}\text { Buyer } \\
\text { holding \& } \\
\text { shortage } \\
\text { cost }\end{array}$ & $\begin{array}{c}\text { Transportation } \\
\text { cost }\end{array}$ & Total cost & $\begin{array}{c}\mathrm{CO}_{2} \\
\text { Emission } \\
\quad(\mathrm{lbs})\end{array}$ \\
\hline 5 & 2 & 2320.89 & 1323.84 & $\$ 3,662.39$ & $\$ 4,641.78$ & $\$ 12,421.40$ & $\$ 5,109.40$ & $\$ 25,835.00$ & $31,585.30$ \\
\hline 10 & 2 & 2319.62 & 1324.14 & $\$ 3,664.40$ & $\$ 4,639.24$ & $\$ 12,419.70$ & $\$ 6,110.21$ & $\$ 26,833.60$ & $37,772.07$ \\
\hline 15 & 2 & 2317.50 & 1324.62 & $\$ 3,667.74$ & $\$ 4,635.01$ & $\$ 12,416.90$ & $\$ 7,118.91$ & $\$ 27,838.50$ & $44,007.68$ \\
\hline 20 & 2 & 2314.55 & 1325.30 & $\$ 3,672.41$ & $\$ 4,629.11$ & $\$ 12,412.90$ & $\$ 8,135.47$ & $\$ 28,849.90$ & $50,291.81$ \\
\hline
\end{tabular}


Table 18: Distance impact on transportation cost

\begin{tabular}{|c|c|c|c|c|c|c|c|c|c|}
\hline $\begin{array}{c}D \\
(\mathrm{~km})\end{array}$ & $n$ & $Q$ & $\begin{array}{c}\text { Reorder } \\
\text { Point }\end{array}$ & $\begin{array}{c}\text { Order \& } \\
\text { Setup } \\
\text { cost }\end{array}$ & $\begin{array}{c}\text { Vendor } \\
\text { Holding } \\
\text { Cost }\end{array}$ & $\begin{array}{c}\text { Buyer } \\
\text { holding \& } \\
\text { shortage cost }\end{array}$ & $\begin{array}{c}\text { Transportation } \\
\text { cost }\end{array}$ & Total cost & $\begin{array}{c}\mathrm{CO}_{2} \\
\text { Emission } \\
(\mathrm{lbs})\end{array}$ \\
\hline 500 & 2 & 1755.61 & 1466.85 & $\$ 4,841.61$ & $\$ 3,511.23$ & $\$ 11,723.30$ & $\$ 1,028.99$ & $\$ 21,105.10$ & $6,360.99$ \\
\hline 1500 & 2 & 1923.68 & 1421.44 & $\$ 4,418.61$ & $\$ 3,847.36$ & $\$ 11,916.40$ & $\$ 2,812.82$ & $\$ 22,995.20$ & $17,388.25$ \\
\hline 2500 & 2 & 2075.05 & 1382.71 & $\$ 4,096.29$ & $\$ 4,150.09$ & $\$ 12,101.20$ & $\$ 4,441.44$ & $\$ 24,789.00$ & $27,456.05$ \\
\hline 3500 & 2 & 2213.78 & 1348.90 & $\$ 3,839.58$ & $\$ 4,427.57$ & $\$ 12,279.00$ & $\$ 5,961.66$ & $\$ 26,507.80$ & $36,853.72$ \\
\hline 4300 & 2 & 2317.50 & 1324.62 & $\$ 3,667.74$ & $\$ 4,635.01$ & $\$ 12,416.90$ & $\$ 7,118.91$ & $\$ 27,838.50$ & $44,007.68$ \\
\hline
\end{tabular}

Table 19: Driving style impact on transportation cost

\begin{tabular}{|c|c|c|c|c|c|c|c|c|c|}
\hline$s$ & $n$ & $Q$ & $\begin{array}{c}\text { Reorder } \\
\text { Point }\end{array}$ & $\begin{array}{c}\text { Order \& } \\
\text { Setup cost }\end{array}$ & $\begin{array}{c}\text { Vendor } \\
\text { Holding } \\
\text { Cost }\end{array}$ & $\begin{array}{c}\text { Buyer } \\
\text { holding \& } \\
\text { shortage cost }\end{array}$ & $\begin{array}{c}\text { Transportation } \\
\text { cost }\end{array}$ & Total cost & $\begin{array}{c}\mathrm{CO}_{2} \\
\text { Emission } \\
(\mathrm{lbs})\end{array}$ \\
\hline 0.8 & 2 & 2242.50 & 1342.10 & $\$ 3,790.42$ & $\$ 4,485.00$ & $\$ 12,316.70$ & $\$ 6,662.64$ & $\$ 27,254.80$ & $41,187.11$ \\
\hline 0.9 & 2 & 2280.39 & 1333.22 & $\$ 3,727.43$ & $\$ 4,560.78$ & $\$ 12,367.10$ & $\$ 6,893.72$ & $\$ 27,549.00$ & $42,615.62$ \\
\hline 1 & 2 & 2317.50 & 1324.62 & $\$ 3,667.74$ & $\$ 4,635.01$ & $\$ 12,416.90$ & $\$ 7,118.91$ & $\$ 27,838.50$ & $44,007.68$ \\
\hline 1.1 & 2 & 2353.88 & 1316.30 & $\$ 3,611.06$ & $\$ 4,707.77$ & $\$ 12,466.20$ & $\$ 7,338.63$ & $\$ 28,123.70$ & $45,365.90$ \\
\hline 1.2 & 1 & 3193.66 & 1148.22 & $\$ 5,009.93$ & $\$ 3,193.66$ & $\$ 13,725.30$ & $\$ 6,420.76$ & $\$ 28,349.60$ & $39,691.83$ \\
\hline
\end{tabular}




\section{CONCLUSION}

In the competitive market today, it is critical for supplier-buyer to work together cohesively and create a partnership in order to be more efficient and keep the costs down. A coordinated single vendor-buyer inventory model is considered under diesel price uncertainty. Decision variables such as optimal number of shipment for forward supply chain, optimal order quantity, optimal reorder level, and expected total cost per unit time is analyzed under the various factors influencing the transportation cost. After analyzing the model with numerical example, it is clear that transportation costs are impacted by various factors, which companies must pay attention to and mitigate strategically.

The model was first validated to see if it gives the optimal order quantity $(Q)$, number of shipments $(n)$ and reorder point $(r)$ for a specific scenario. The results reflected that two big costs impacting total cost is buyer's holding cost, shortage cost and transportation cost. Then the model was used to further determine how the lead time changes the optimal $Q, n, r$ values. When the lead time increased from 7 to 42 days, it was noticed that $n$ changed from 2 to 1 . If product rate allows, the $Q$ increases per shipment so that customer has enough to avoid negative impact of shortage. But this increased the holding cost. Holding cost must be reduced or shortage cost should be improved to minimize the total cost where lead-time is high. After seeing the effects of the lead-time, the model was then altered to see how the total cost changed with varying production rates (low vs high). This proved that at a certain point in each production rate, it makes more financial sense to ship more quantity in less \# of shipments because holding and shortage costs are outweighed by order, setup cost, vendor holding cost and transportation cost. When lead-time is small, the impact of production rate is not very significant but when lead-time is high, it is critical to have high production rate to minimize overall supply chain cost.

The model was then altered with various truck features to determine how transportation cost is affected. When the truck engine efficiency changes from $36 \%$ to $44 \%$ the total cost increases by $\$ 1406$. Similarly, when road slope changes from 0 to $0.4 \mathrm{rad}$, the model demonstrated that the total cost increases by $\$ 4076$. This shows the importance of picking a route with the least amount of slope change. When truck features like aerodynamic resistance was improved, the total cost dropped approximately $\$ 700-\$ 1000$. Another variable is the Canadian weather, which has an 
impact on the supply chain cost because increase in the density of air also increases the aerodynamic drag. Finally, product weight has a significant impact on transportation cost. Model results show that when product weight changes from $5 \mathrm{~kg}$ to $20 \mathrm{~kg}$, the total expected cost increases by approximately $\$ 3000$. It is also evident that the most optimal solution is not always the most environmentally friendly.

Overall, it is critical to understand how lead-time and production rates affect the total supply chain cost. However, it is just as important to also recognize how companies' fleet, environment, and drivers impact the total expected cost. An improvement in transportation cost can help firms financially and environmentally. Future research topics to consider is to include defective products and deteriorating products should be considered in this model. It will be beneficial to understand cost in cases where buyer stores defective item in their facility and sends it all back to vendor. Cost of rework can also be incorporated into this model. Also, carbon cost should be incorporated into this model and various carbon cap policies. As many companies commit to reduce carbon footprint, understanding how trucks consume diesel and carbon cap policies can help companies develop realistic objectives and robust strategies to meet their sustainability goals. 


\section{REFERENCES}

Banerjee, A., Kim, S. L., and Burton, J. (2007). Supply chain coordination through effective multi-stage inventory linkages in a JIT environment. International Journal of Production Economics, 101(1), 271-280.

Baumol, W., and Vinod, H. D. (1970). An inventory theoretic model of freight. Management Science, 16(7), 413 - 421.

Clewlow, L., \& Strickland, C. (2000). Energy derivatives: Pricing and risk management. Lacima Publications.

Cummins. Secrets of Better Fuel Economy. Cummins.

Curry, T., Liberman, I., and Hoffman-Andrews, L. (2012). Reducing Aerodynamic Drag and Rolling Resistance from Heavy-Duty Trucks. San Francisco: M.J. Bradley and Associates LLC.

Dey, O., and Giri, B. C. (2014). Optimal vendor investment for reducing defect rate in a vendorbuyer integrated system with imperfect production process. International Journal of Production Economics, 155, 222-228.

Dittmann, P. (2014). Managing risk in the global supply chain. Knoxville: The Global Supply Chain Institute, University of Tennessee.

Dixit, A. K., \& Pindyck, R. S. (1996). Investment under uncertainty. Princeton: Princeton University Press.

Ehsani, M., and Fadai, D. (2016). Modeling of vehicle fuel consumption and carbon dioxide emissionin road transport. Renewable and Sustainable Energy Reviews, 53, 1638-1648.

Environment Canada. (2013). Canada's Emissions Trends.

Environment Protection Agency. (2010). Managing Supply Chain Greenhouse Gas Emissions. EPA.

Franzese, O. (2011). Effect of Weight and Roadway Grade on the Fuel Economy of Class-8 Freight Trucks. Tennessee: OAK RIDGE NATIONAL LABORATORY.

Glock, C. H. (2012). Coordination of a production network with a single buyer and multiple vendors. International Journal of Production Economics, 135(2), 771-780.

Glock, C. H. (2012). The joint economic lot size problem: A review. International Journal of Production Economics, 135(2), 671 - 686.

Goodyear. (2008). Factors Affecting Truck Fuel Economy. 
Goyal, S. (1976). An integrated inventory model for a single supplier-single customer problem. International Journal of Production Research, 15, 107-111.

Goyal, S. K., Huang, C. K., and Chen, K. C. (2003). A simple integrated production policy of an imperfect item for vendor and buyer. Production Planning \& Control, 14(7), 596-602.

Hill, R. M. (1997). The single-vendor single-buyer integrated production-inventory model with a generalised policy. European Journal of Operational Research, 97(3), 493-499.

Jofred, P., and Oster, P. (2011). CO2 Emmisions from Freight Transport and the Impact of Supply Chain Management, Master of Science Thesis, KTH Stockholm, Industrial Engineering and Management.

Kim, T., and Glock, C. H. (2013). A multi-stage joint economic lot size model with lead time penalty costs. Computers \& Industrial Engineering, 66(1), 133-146.

Koenig, K. M. (2008). Inside Swedwood: IKEA'S First U.S. Plant. Woodworking Network.

Konur, D., and Geunes, J. (2011). Analysis of traffic congestion costs in a competitive supply chain. Transportation Research, 47(1), 1-17.

Lee, C. Y. (1986). The economic order quantity for freight discount cost. IIE, 18(3), 318 - 320.

Lee, S., and Kim, D. (2014). An optimal policy for a single-vendor single-buyer integrated production-distribution model with both deteriorating and defective items. International Journal of Production Economics, 147, 161-170.

Li, S., Haefen, R. V., and Timmins, C. (2008). How do gasoline prices affect fleet fuel economy? Cambridge: National Bureau of Economic Research.

Lin, Y. J. (2009). An integrated vendor-buyer inventory model with backorder price discount and effective investment to reduce ordering cost. Computers \& Industrial Engineering, 56(4), 1597-1606.

Oak Ridge National Laboratory. (2014). 2014 Vehicle Technology Market Report. Oak Ridge, TN: Center for Transportation Analysis.

Patten, J., McAuliffe, B., Mayda, W., and Tanguay, B. (2012). Review of Aerodynamic Drag Reduction Devices for Heavy Trucks and Buses. Ottawa: National Research Council of Canada.

Russell, D., Coyle, J. J., Ruamsook, K., and Thomchick, E. A. (2014). The real impact of high transportation costs. Logistics Supply Chain Quarterly, 2014(Q1). 
Sajadieh, M. S., Akbari J., M. R., and Modarres, M. (2009). Developing a coordinated vendorbuyer model in two-stage supply chains with stochastic lead-times. Computers \& Operations Research, 36(8), 2484 - 2489.

Schwartz, E., and Smith, J. E. (2000). Short-term variations and long-term dynamics. Management Science, 46(7), 893-911.

Siltanen, T. (2010). Truck Tyre Rolling Resistance and Fuel Economy \& Safety. Nokian Tyres.

Subbarao, P. M. Resistance Forces on A Vehicle. Estimation of Vehicle Demands. Delhi: IIT Delhi.

Thiruvengadam, A., Pradhan, S., Thiruvengadam, P., Besch, M., and Carder, D. (2014). HeavyDuty Vehicle Diesel Engine Efficiency Evaluation and Energy Audit. Morgantown, WV: West Virginia University.

Toptal, A., Ozlu, H., and Konur, D. (2014). Joint decisions on inventory replenishment and emission reduction investment under different emission regulations. International Journal of Production Research, 52(1), 243-269.

Wee, H. M., and Widyadana, G. A. (2013). Single-vendor single-buyer inventory model with discrete delivery order, random machine unavailability time and lost sales. International Journal of Production Economics, 14(2), 3574-579.

Whistler, D. (2011). Fleet Owner. Retrieved July 4, 2016, from Fuel economy 101: http://fleetowner.com/fuel_economy/fuel-economy-0701 